\title{
Reducing the Incidence of Pressure Injuries in Adult ICU Patients at McAllen Medical Center with the Implementation of a Pressure Injury Preventive Bundle: A Quality Improvement Project
}

Cheryl Cruz

University of St. Augustine for Health Sciences, c.cruz@usa.edu

DOI: https://doi.org/10.46409/sr.OBVT6457

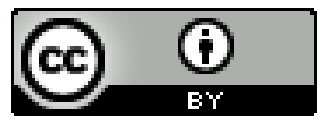

This work is licensed under a Creative Commons Attribution 4.0 License.

Follow this and additional works at: https://soar.usa.edu/scholprojects

Part of the Adult and Continuing Education Commons, Critical Care Nursing Commons, and the Skin and Connective Tissue Diseases Commons

\section{Recommended Citation}

Cruz, C. (2020). Reducing the Incidence of Pressure Injuries in Adult ICU Patients at McAllen Medical Center with the Implementation of a Pressure Injury Preventive Bundle: A Quality Improvement Project. [Doctoral project, University of St Augustine for Health Sciences]. SOAR @ USA: Student Scholarly Projects Collection. https://doi.org/10.46409/sr.OBVT6457

This Scholarly Project is brought to you for free and open access by the Student Research at SOAR @ USA. It has been accepted for inclusion in Student Scholarly Projects by an authorized administrator of SOAR @ USA. For more information, please contact soar@usa.edu, erobinson@usa.edu. 
Reducing the Incidence of Pressure Injuries in Adult ICU Patients at McAllen Medical Center with the Implementation of a Pressure Injury Prevention Bundle: A Quality Improvement Project Cheryl P. Cruz, MAN, RN School of Nursing, University of St. Augustine for Health Sciences NUR7803: DNP Practicum III This Manuscript Partially Fulfills the Requirements for the Doctor of Nursing Practice Program and is Approved by:

Dr. Camille Payne, PhD, RN

Dr. Candida Constantine-Castillo, DHA, MBA, MSN, RN, FACHE, CEN, CPHQ, CPHRM, NEA-BC, HACP, CNML

August 02, 2020 


\section{University of St. Augustine for Health Sciences \\ DNP Scholarly Project \\ Signature Form}

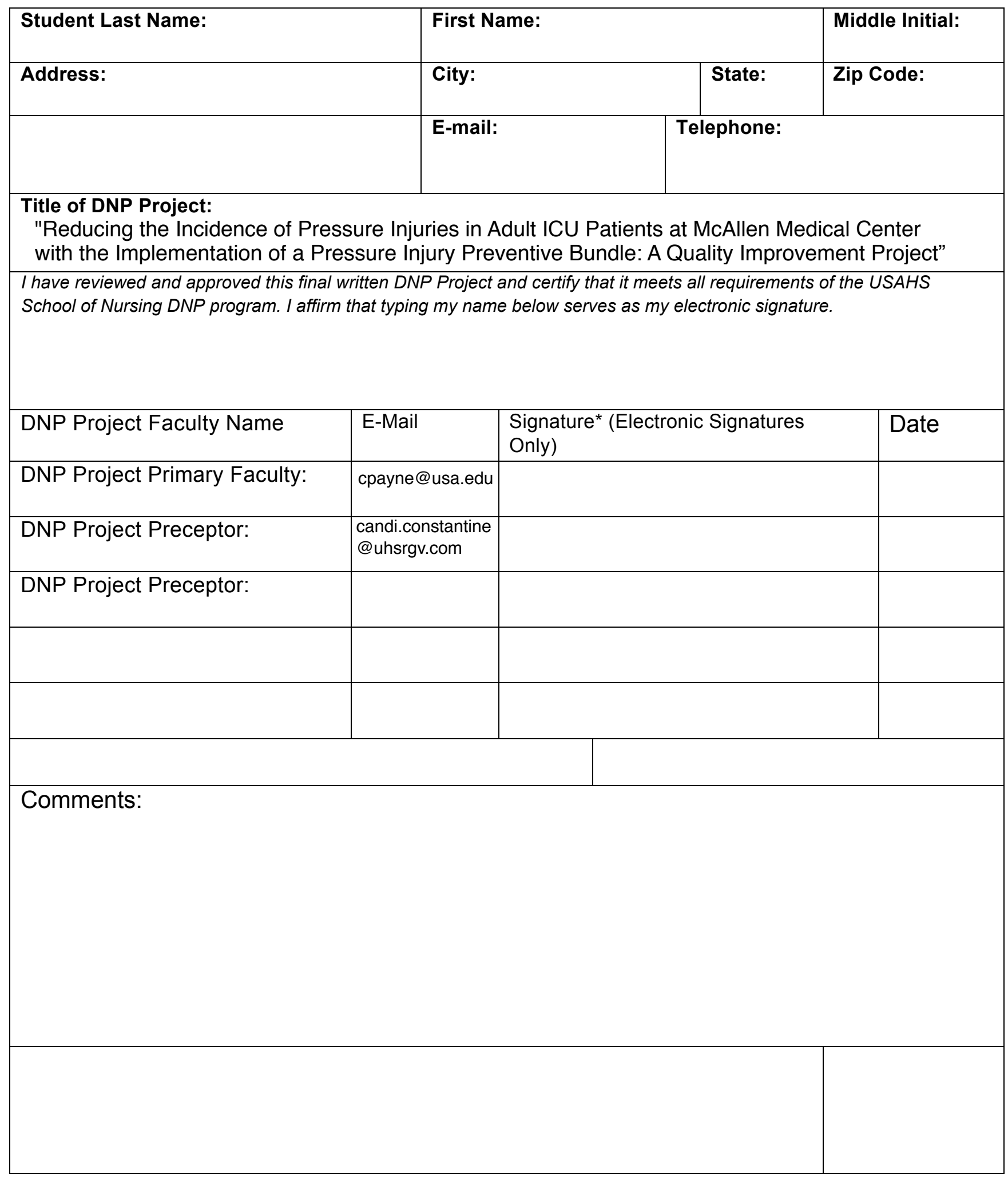




\begin{abstract}
Practice Problem: Pressure injuries (PIs) are a significant healthcare problem globally. Adult patients in the intensive care setting are especially vulnerable to the development of PIs given the acuity of their diagnoses requiring extensive treatments, procedures and the use of multiple medical devices.
\end{abstract}

PICOT: The PICOT question that guided this project was, "In adult intensive care unit (ICU) patients, how does the effect of implementing a pressure injury prevention bundle compare in patients who received the bundle, and patients receiving standard pressure injury prevention in reducing the incidence of pressure injuries after two months?”

Evidence: Evidence exist that bundle implementation significantly reduced incidence of PIs in adult ICU patients.

Intervention: A pressure injury preventive bundle consisting of six evidence-based interventions were consistently and collectively implemented to reduce incidence of PIs in adult ICU patients at a tertiary hospital in South Texas. Further, a multidisciplinary approach, monitoring, auditing, and providing constructive feedback to staff were employed to ensure appropriate implementation and increase likelihood of achieving positive outcomes.

Outcome: Findings revealed a 7.37\% reduction in incidence after two months of bundle implementation. Also, findings showed more than $90 \%$ compliance with five out of the six components of the bundle.

Conclusion: The reduction in the incidence of PIs with the implementation of a pressure injury preventive bundle in adult ICU patients was not statistically significant. However, the reduction indicated a clinically meaningful improvement in pressure injury outcomes two months after implementing the bundle. 
Reducing the Incidence of Pressure Injuries in Adult ICU Patients with the Implementation of a Pressure Injury Prevention Bundle: A Quality Improvement Project

Pressure injuries (PIs) ae localized injuries to the skin and or its surrounding tissues that often occur over bony prominences or related to a medical or other device (European Pressure Ulcer Advisory Panel [EPUAP] and National Pressure Ulcer Advisory Panel [NPUAP], 2009). The injury can present as intact skin or an open ulcer and may be painful. The injury occurs as a result of intense and/or prolonged pressure or pressure in combination with shear (National Pressure Ulcer Advisory Panel, 2009).

Most PIs are preventable (Australian Wound Management Association, 2012). However, the prevalence and incidence of PIs are usually higher in the intensive care unit (ICU) compared to general care areas (Cuddigan, 2012). Critical patients admitted in the ICU have greater risks for the development of PIs as they are more likely to have severe illness requiring extensive treatments and multiple medical devices, on mechanical ventilator, sedated, immobile, hemodynamically unstable requiring multiple pharmacological therapies, incontinent, and have poor nutrition (Amr,Yousef, Amirah, \& Alkurdi, 2017; Anderson et al., 2015; Coyer et al., 2015; Richardson, Peart, Wright, \& MCcullaugh, 2017; Tayyib \& Coyer, 2017; Tayyib, Coyer, \& Lewis, 2015). Moreover, the environmental factors and complicated care in the ICU inevitably increase the risks for PIs (Tayyib, Coyer, \& Lewis, 2016).

This paper aimed to evaluate the effect of pressure injury preventive bundle implementation after two months in reducing the incidence of pressure injuries in adult ICU patients in a tertiary hospital in South Texas.. Included in the paper are a discussion on the significance of the practice problem, PICOT question, theoretical framework, a synthesis of reviewed literature, practice recommendations, and project setting. Additionally, the paper 
outlined the project's mission, vision, and objectives, project plan, project evaluation, discussion and implications, dissemination along with a conclusion.

\section{Significance of the Practice Problem}

Pressure injuries (PIs) are a significant global healthcare problem (Coyer et al., 2015; Tayyib, Coyer, \& Lewis, 2015). PIs cause substantial harm to patients by causing pain and severe infections; deterring recovery; lengthening hospital stays; and increasing healthcare costs, thus creating financial strain on patients and their families (Grealy \& Chaboyer, 2012). PIs are indicators of the quality of care patients receive while admitted to the hospital (Coyer et al., 2015). Therefore, PIs are a priority for patient safety and risk management concerns (Soban, Hempel, Munjas, Miles, \& Rubenstein, 2011).

According to Lyder et al. (2012), acute care hospitals treat approximately 2.5 million PIs every year with an estimated treatment costs of $\$ 11$ billion annually in the United States. PIs are associated with about 60,000 deaths per year (Lyder et al., 2012). The Center for Medicare and Medicaid Services (CMS) mandated a non-payment for the treatment of hospital-acquired PIs and caused tremendous financial burden on healthcare organizations (Ober \& Craven, 2008). The prevalence of PIs is higher in the intensive care setting (Berlowitz, 2014; Cuddigan, 2012). According to Berlowitz (2014), the worldwide prevalence rate of PIs varies from $3 \%$ to $50 \%$ in the ICU. The incidence rate in the ICU was as high as 39.3\% in a Saudi Arabian study (Tayyib, et al., L2015) and up to 50\% in Australia (Coyer et al., 2015).

According to the EPUAP and NPUAP (2009), PIs are highly preventable. The prevention of PIs requires significant amounts of limited resources in nursing care and finances (Zuo \& Meng, 2015). However, the cost of treating pressure injury per patient per day is considerably higher than the cost of preventing PIs (Demarre et al., 2015). Therefore, prevention must be a 
crucial component of patient care to meaningfully improve care and reduce the costs associated with treatment in the ICU (Zuo \& Meng, 2015).

In February of 2019, the ICU at a South Texas hospital had a 20.68\% pressure injury incidence rate (Hillrom, 2019). This incidence rate is an indication for a need to carefully examine the current ICU care practices for patients who are at high risk for developing PIs. The high incidence of PIs requires the implementation of an evidence-based intervention to effectively reduce the incidence of PIs in adult ICU patients and improve pressure injury outcomes.

\section{Framework of the Problem}

The Virginia Henderson Need Theory views the patient as an individual requiring assistance in achieving independence and wholeness of mind and body (Henderson, 1960). Henderson's theory outlined self-directed nursing functions, goals of interdependence for the patient, and self-help concepts (Pokorny, 2014). Henderson (1960) advocated the utilization of the nursing process and contended that the nursing practice is independent of the physician's practice. The nurse interacts with the patient and acts as a substitute, a collaborator, and a partner to form a meaningful nurse-patient relationship (Harmer \& Henderson, 1995). Further, Henderson (1960) stresses that the nurses' role is to effectively assist the individual, sick or well, to decisively perform activities that contribute to health and recovery that he would independently perform if he had the needed strength, will, or knowledge, and accomplishing it as promptly as possible. Additionally, the nurse, according to Henderson, must be a scientific problem solver and should be educated in both arts and science of nursing to effectively practice (Harmer \& Henderson, 1995). 
Virginia Henderson's Need theory has a three-fold application to this project. First, her theory offers a framework to accurately identify the patient's needs and methodically address them through the nursing process (George, 2011). Second, the theory centers on the nurses' knowledge, skills, and competence to carry out independent nursing interventions that support a patient's health and wellbeing. The nursing staff has the expertise to assist patients back to health, prevent PIs, and promote early recovery (Coyer et al., 2015). Third, the theory advocates for recognizing and attending to the nursing staff's need for education, training, and support to prepare them adequately for the bundle implementation (Tayyib \& Coyer, 2016).

\section{Scholarly Question}

The PICOT question for the change project is: In adult ICU patients, how does the effect of implementing a pressure injury prevention bundle compare in patients who received the bundle, and patients receiving standard pressure injury prevention in reducing the incidence of pressure injuries after two months? Adult patients age 18 years and older admitted in the ICU served as the target population of the study. Patients who obtained a Braden risk score of 16 and below who did not have pressure injuries upon admission to the ICU were included as participants in the study. Pediatric patients were excluded.

The implementation of a pressure injury prevention bundle is the intervention. Six individual evidence-based pressure injury preventive interventions are collectively and consistently implemented to produce the desired positive outcomes (Horner \& Bellamy, 2012; Tayyib \& Coyer, 2016). The components of the bundle consist of using the Braden scale; turning the patient every two hours; obtaining a nutritional consult; application of protective dressings to the sacral area, bilateral heels, and on body parts where medical devices are in use; use of air vented mattresses on top of regular mattresses; and education and training to the staff. Patients 
who received the intervention were compared to patients who received standard pressure injury prevention after two months. Standard pressure injury prevention refers to the individual components of the pressure injury prevention bundle with the exclusion of the education and training.

\section{Literature Search Strategy}

The search for evidence to support the use of a pressure injury preventive bundle in reducing the incidence of pressure injury in adult ICU patients commenced by using the headings and keywords "pressure injuries," "pressure ulcers," "preventive bundle," "adult patients," and “intensive/critical care units." Three databases that include CINAHL, PubMed, and Google Scholar were employed to narrow the search into 45 articles for review. Articles included were published from 2012- 2019, written in English and related to the PICOT question. The articles were then reviewed for any duplicates. After screening the titles and abstracts that did not relate to the PICOT question, 26 articles were excluded; two articles did not have full texts and were excluded. A total of eleven pieces of literature were included. Nine were quantitative studies, one was qualitative, and one was a systematic review.

\section{Literature Search Results and Evaluation}

A PRISMA model search strategy is provided in Appendix D. Based on the level of evidence outlined by the Strength of Recommendation Taxonomy (SORT) (Ebbel et al., 2014), the seven quantitative studies provided level three evidence, and the other two were level two; the qualitative study had level three evidence; and the systematic review had level one evidence. Individual articles are listed with the level of evidence in Appendix A and B.

\section{Themes from the Literature}

The reviewed literature offers evidence applicable to address the components of the 
PICOT question. Following an in-depth evaluation of the literature utilizing evidence and synthesis tables provided in Appendix A, B, and C, specific themes were identified. The themes are discussed in the following section.

\section{Rationale for Using a Bundle}

The term bundle refers to a set of three to six evidence-based interventions consistently and collectively implemented in clinical practice to improve patient outcomes (Horner \& Bellamy, 2012; Tayyib et al., 2015). A bundle implementation is specific, clear, simple, increases compliance, and is effective in targeting and improving certain conditions like ventilator-associated pneumonias (VAPs), central line-associated systemic infections (CLABSIs), and sepsis (Anderson, et al., 2015; Carino, Ricci, Bartula, Manzano, \& Sargeant, 2012; Richardson et al., 2017; Tayyib et al., 2016). Additionally, a bundle is reliable, easy to implement, and can be contextualized in the ICU (Tayyib \& Coyer, 2017).

PIs are often predictable and preventable; however, the incidence and prevalence of such injuries in the ICU setting remains higher compared to the general areas (Berlowitz, 2014). Evidence suggests that PIs could be prevented with the implementation of PI guidelines or a care bundle (Gray-Siracusa \& Schrier, 2011). However, a bundle approach is more effective than clinical guidelines because of the mandatory and audited nature of a bundle compared to the advisory nature of a clinical guideline (Gill, 2015; Robb et al., 2010; Tayyib et al., 2015).

According to Tayyib et al. (2015), the intensive care context poses numerous challenges in preventing PIs in adult ICU patients given their high acuity, invasive interventions, and the treatments they receive. Further, the complexity of the ICU environment, nursing workload, time demands, reliance on technological support, and critical illness negatively affects the basic care to prevent PIs in critically ill patients (Tayyib \& Coyer, 2016). Hence, it is crucial to develop a 
bundle based on high-quality evidence and contextually compatible pressure injury preventive measures (Tayyib et al., 2015).

\section{The Bundle Components}

A critical appraisal of current evidence is crucial in determining the essential components of a pressure injury prevention bundle (Anderson et al., 2015; Richardson et al., 2017; Tayyib \& Coyer, 2016). Some individual PU prevention strategies have been studied and proven to be useful in the reduction of PIs developed. The individual strategies can be grouped to reduce PU development ((Tayyib, \& Coyer, 2016).

The first step in effective pressure injury prevention is a prompt and accurate identification of risk factors. To accurately identify the patients' risk factors for PIs, the National Pressure Ulcer Advisory Panel (NPUAP), European Pressure Ulcer Advisory Panel (EPUAP), and Pan Pacific Pressure Injury Alliance (PPPIA) (2014) recommend the incorporation of Braden risk and skin assessment to guide the implementation of effective strategies. The Braden scale is a validated instrument for estimating the risks for the development of PIs (Zuo \& Meng, 2015). Braden scores range from 6 to 23; score of 16 or lower indicates high risk for PIs and a score of 17 and above signifies low risk (Ayelo \& Braden, 2002). The sensitivity of the Braden Scale to identify patients at risk for PI development ranges from $71 \%$ to $100 \%$ (Chan, Pang, \& Kwong, 2009). Multiple studies included the Braden risk and skin assessment as an essential component in the bundle implementation (Amr et al., 2017; Anderson et al., 2015; Gill, 2015; Richardson et al., 2017; Tayyib et al., 2015; Tayyib et al., 2016). Skin assessment should occur immediately following admission, and once every shift in the ICU, or more often in patients with high risk for PIs (Zuo \& Meng, 2015). 
Appropriate prevention strategies must be implemented to relieve intensive and prolonged pressure once high risks patients are identified (Tayyib \& Coyer, 2016). Patients who are unable to reposition themselves are logically more likely to be subjected to prolonged external mechanical forces (Zuo \& Meng, 2015). Repositioning is the most commonly employed strategy to reduce prolonged pressure, shear, and friction (Anderson et al., 2015; Gill, 2015; Tayyib et al., 2015). A two-hour repositioning interval is considered standard for all immobilized and critically ill patients (Amr et al., 2017; Carino et al., 2012; Richardson et al., 2017). However, repositioning every three hours has shown positive effect in reducing the incidence of pressure injuries in adult ICU patients when incorporated in a preventive bundle implementation (Coyer et al., 2015; Tayyib et al., 2016). According to Anderson et al. (2015), turning the patient every two or three hours remained difficult to accomplish. Richardson et al. (2017) argued that this is mostly related to patients' instability while Carino et al. (2012) posited that the challenge is due to the very strict definition of success for this bundle component.

Early identification of the patient's nutritional status upon admission is critical to screen patients and initiate an early nutritional supplementation (Amr et al., 2017; Carino et al., 2012; Coyer et al., 2015; Tayyib et al., 20016; Tayyib et al., 2015; Zuo \& Meng, 2015). Carino et al. (2015) explained the need for a nutritional assessment to evaluate parameters like pre-albumin, albumin, and protein, as these parameters have been associated with PI development. Nurses must advocate for the earliest possible nutritional screen and supplementation when necessary (Zuo \& Meng, 2015).

The sacrum and the heels are the most common area for PI development while the nares and neck are the most common areas for medical device related ulcers (MDRU) (Amr et al., 2017; Tayyib et al., 2015; Zuo \& Meng, 2015). Application of protective dressings, soft silicone 
foam dressing, to the sacral area and heels has been documented as an effective prevention for pressure injury both in general care and the critical care unit (Amr et al., 2017; Byrne, et al., 2016; Kalowes, Messina, \& Li, 2016; Santamaria et al., 2015). Using protective dressings in securing and stabilizing devices also could minimize the risk for MDRU (Tayyib et al., 2015).

Using pillows and wedges to support suspension of bony prominences off bed surfaces is a standard practice (Zuo \& Meng, 2015). However, air mattresses outperformed conventional hospital mattresses in preventing PIs in the ICU (McInnes, Jammali-Blasi, Bell-Syer, Dumville, \& Cullum, 2011). Air mattresses are redistribution surfaces designed to minimize pressure and shear are available and recommended for utilization in high-risk patients (Amr at al., 2017; Anderson et al., 2015; Carino et al., 2012; Richardson et al., 2017; Tayyib \& Coyer, 2017; Tayyib et al., 2016; Tayyib et al., 2015).

Key to implementing the bundle approach is applying strategies to increase the staff's level of awareness of the protocol through staff education and training (Amr et al., 2017; Coyer et al., 2015; Roberts et al., 2016; Tayyib \& Coyer, 2017; Tayyib et al., 2015). Ongoing bedside sessions, monthly discussions and updates, brochures, interactive in-service, group presentation regarding skin assessment, magnitude of the pressure injury problem, and components of the bundle implementation can be effectively used in promoting staff engagement and compliance and contributed to the successful results of bundle implementation in reducing the incidence of pressure injuries (Amr et al., 2017; Coyer et al., 2015; Roberts et al., 2016; Tayyib \& Coyer, 2017; Tayyib et al., 2015).

\section{Multidisciplinary Approach}

A multidisciplinary approach in the bundle implementation is needed for success. Gill (2015) contended that coordinating with multidisciplinary team could be challenging. However, 
the utilization of champions and ICU wound care team consisting of team members from other disciplines yielded positive outcomes when used to implement the bundle (Amr et al., 2017; Coyer et al., 2015; Gill, 2015; Richardson et al., 2017; Tayyib \& Coyer, 2017; Tayyib et al., 2016). A multidisciplinary PI group is an important component of quality improvement initiatives (Richardson et al., 2017).

\section{Evaluation of Staff Compliance}

The successful implementation of the bundle approach demands an evaluation of the nursing staff compliance with the bundle implementation (Amr et al., 2017; Anderson et al., 2015; Carino et al., 2012; Coyer et al., 2015; Gill, 2015; Tayyib \& Coyer, 2017; Tayyib et al., 2016; Tayyib, et al., 2015). An adherence or compliance checklist, cyclical feedback, weekly audit, feedback, monitoring, self-reporting, and observations are recommended methods of evaluating staff compliance with the bundle (Amr et al., 2017; Anderson et al., 2015; Carino et al., 2012; Coyer et al., 2015; Gill, 2015; Richardson et al., 2017; Tayyib \& Coyer, 2017; Tayyib et al., 2016; Tayyib et al., 2015). Evaluation of staff compliance to the bundle components ensured that the components were implemented the way they were intended to (Amr et al., 2017; Coyer et al., 2015).

Nurses positively responded to pressure ulcer bundle implementation and perceived implementation as beneficial to the team approach and patient involvement as the nurses' awareness to bundle implementation increased with time (Roberts et al., 2016). The nurses needed time to be familiarized with the bundle before they could implement it in their current practice. The nurses' familiarity with the bundle increased staff engagement in the bundle implementation (Tayyib et al., 2016). 


\section{Effects of a Bundle Implementation}

Coyer et al. (2015) applied the holistic theory whereby the whole being better than the total of its parts and tested Inspire, a bundle protocol. The cumulative incidence of PIs in the intervention group (18.1\%) was significantly reduced when compared with the $30.4 \%$ cumulative incidence in the control group (2015). However, Tayyib et al. (2015) argued that the bundle approach guidelines for PI prevention are not well defined for ICU patients. They conducted a study to evaluate the effectiveness of the bundle approach in reducing the incidence of pressure ulcers in adult ICU patients in Saudi Arabia. Despite the lack of guidelines on bundle implementation specific for ICU patients, Amr et al. (2017) opted to implement the PRESSURE bundles in the ICU patients in Saudi Arabia to reduce the increasing incidence of sacral pressure ulcers.

Coyer et al., (2015), and Tayyib et al. (2015) both concluded in their findings that the implementation of the bundle approach in ICU patients was effective in reducing the incidence, number, and severity of pressure ulcers developing later in their stay in the ICU. Also, Amr et al. (2017) supported the effectiveness of the bundle approach and reported a significant reduction in the incidence of sacral ulcers after the implementation of the pressure bundle approach in ICU patients in a Riyadh Hospital.

The implementation of the bundle approach was likewise effective in reducing medical equipment- related mucous injuries in ICU patients (Coyer et al., 2015; Tayyib et al., 2015). Similarly, various studies reported significant reduction in the incidence of pressure injuries in adult ICU patients post bundle implementation (Anderson et al., 2015; Carino et al., 2012; Gill, 2015; Richardson et al., 2017; Roberts et al., 2016; Tayyib \& Coyer, 2017; Tayyib et al., 2016). PI prevention bundles resulted in improved patient outcomes in the adult ICU patients in the 
United States, Australia, Saudi Arabia, as well as other international settings (Amr et al., 2017; Anderson et al., 2015; Carino et al., 2017; Coyer et al., 2015; Gill, 2015; Richardson et al., 2017; Roberts et al., 2016; Tayyib \& Coyer, 2017; Tayyib et al., 2016; Tayyib et al., 2015).

The literature reviewed provided available evidence to answer the PICOT question: In adult ICU patients, how is the effect of implementing a pressure injury prevention bundle compare to patients who received a pressure injury prevention bundle and patients who received standard pressure injury prevention? The answer is that, the bundle implementation is more effective in reducing the incidence of pressure injuries in adult ICU patients compared to those receiving standard pressure injury prevention (Amr, et al., 2017; Anderson et al., 2015; Carino et al., 2012; Coyer et al., 2015; Gill, 2015; Richardson et al., 2017; Roberts et al., 2016; Tayyib \& Coyer, 2017; Tayyib, Coyer, \& Lewis, 2016; Tayyib, et al., 2015).

\section{Practice Recommendations}

Based on the synthesis of the literature, the recommendation is to implement a pressure injury prevention bundle in adult ICU patients at a South Texas hospital to reduce the incidence of pressure injuries. The components of the bundle will include: risk assessment using the Braden scale along with a head-to-toe skin assessment per hospital policy; turning the patient every two hours; obtaining nutritional consultation; application of protective devices to the sacrum, heels, and areas where medical devices are in use; use of air vented waffle mattresses on top of regular mattresses; and staff education and training. Key implementation strategies will include increasing staff awareness of the bundle components, along with daily monitoring, auditing, ongoing bedside support, and providing constructive feedback to the staff by a multidisciplinary team, the ICU bundle champions. A compliance checklist will be utilized to ensure proper implementation and evaluate compliance. 


\section{Project Setting}

The ICU of a 431-bed tertiary hospital in South Texas served as the setting for the project. The hospital is a Level II Trauma Center in South Texas and is the only Certified Primary Stroke Center in Hidalgo County (McAllen Medical Center, 2019). Trauma and stroke patients admitted to the ICU have higher acuity and increased risks for the development of pressure injuries. The ICU has a 36- bed capacity that provides highly skilled critical care for pediatric and adult trauma patients, adult medical-surgical patients, and neurological patients requiring intensive care services (McAllen Medical Center, n.d.). Clinical providers include a group of ICU trained physicians available 24 hours a day, trauma doctors, nurse practitioners, staff nurses, physical therapists, occupational therapist, respiratory therapists, and certified nurse assistants.

Considering the nurse-patient ratio in the ICU is critical. The nurse to patient ratio in the ICU can vary. The nurse-patient ratio depends on the patient acuity. An ICU nurse can have one to a maximum of three ICU patients, and up to four for downgraded patients waiting for medical or telemetry beds. A nurse to patient ratio of 1:1 will provide the nurse more time to focus on preventive interventions compared to a nurse to patient ratio of 1:3 or 1:4.

Organizational need for the project stemmed from the recommendation of the Chief Nurse Officer (CNO) and the ICU Director. The continued increasing incidence of PIs in adult ICU patients is a recognized need in the facility. Both nursing leaders verbally expressed full support of the project implementation.

Stakeholders for the change project includes the Chief Nurse Officer (CEO), CNO, ICU Director, ICU Physicians, ICU staff (charge nurses, staff nurses, and certified nursing assistants), wound care nurses, respiratory therapists, representatives from the clinical informatics, quality 
department, risk management, physical therapy, occupational therapy, education department, and a dietician, along with the patients, and family members.

Sustainability plans include the utilization of a multidisciplinary team; an ICU bundle champions, comprised of ICU RN champions (charge and frontline staff and wound care nurses; respiratory therapists; physical therapists; occupational therapist, and a dietician. The ICU RN champions will be monitoring, auditing, providing ongoing bedside support and constructive feedback to the staff to ensure compliance with all the bundle components. Also included in the sustainability plans are regular updates of the key stakeholders of the project's progress, ongoing organizational and nursing leadership support, rewarding and recognizing staff for their compliance, incorporating the bundle components into the EHR nurses workflow documentation, and onboarding of new ICU staff during hospital and unit orientation, e-learning, and ongoing bedside education.

An organizational strength, weakness, opportunities, and threats (SWOT) analysis was conducted to assess the organization. Strengths identified consist of leadership support and frontline staff support. Lack of visible leadership in the ICU, availability of supplies used for preventing PIs, staffing, and inconsistencies of staff in staging PIs were considered weaknesses. Two opportunities identified include utilization of the ICU bundle champions and educational training for the staff. Some of the threats are increasing treatment costs for PI, legal liabilities, and putting the hospital reputation at risk. The SWOT analysis is provided in Appendix E.

\section{Project Vision, Mission, and Objectives}

The vision of the project is to improve pressure injury outcomes in adult ICU patients.. This vision is in alignment with the hospital's vision of achieving the highest quality of compassionate care through innovation and visionary leadership. Reducing the incidence of 
pressure injuries is the project's mission and is consistent with the hospital's mission of providing superior quality healthcare services that employees can be proud of (McAllen Medical Center, 2019).

Short-term goals for the project include a $10 \%$ or more reduction in the incidence of PIs and the number of patients with severe stages of PIs, along with $90 \%$ or higher staff compliance with all bundle components in two months. The long-term goals are the achievement of a $20 \%$ or more reduction in the incidence of PIs, the strategic management of risks to avoid declining staff compliance, incorporation of the bundle implementation in the policy and procedure for skin integrity and inclusion of the bundle documentation in the electronic health record, and to ensure sustained positive-pressure injury-related outcomes and investment returns after six months.

\section{Project Plan}

The Model of Improvement framework will be most appropriate for my project to create a system level change (Institute for Healthcare Improvements [IHI], 2019). In 1990, the Associates in Process Improvement developed the framework. The framework is structured as an algorithm to achieve improvement goals through learned experience and intentional action (Langley, Nolan, Nolan, Norman, \& Provost, 2009). Healthcare organizations have successfully used this model to improve numerous health care processes and outcomes (IHI, 2019). The model consists of two parts: three focal questions that need to be addressed in any order and the Plan, Do, Study, and Act (PDSA) cycle to evaluate the change in the real work setting. According to the IHI (2019), the model utilizes careful and thoughtful planning in starting the change project and is guided by these three fundamental questions.

1. What are we trying to accomplish? 
2. How will we know a change is an improvement?

3. What changes can we make that will result in improvement?

The model's utilization of the Plan, Do, Study, and Act (PDSA) method allowed the frontline staff team to evaluate the success of an intervention and either adopt or abandons the associated intervention and move on to the next with each cycle (Provost, 2019). Also, the model offers simplicity, applicability, and accessibility for frontline staff with minimal quality improvement training or experience (DeOreo et al., 2012).

The steps of the Model of Improvement (IHI, 2019) consist of forming the team; setting aims; establishing measures; selecting changes; testing the changes; implementing the changes; and spreading the changes, These steps are valuable in the discussion of the proposed change project.

\section{Forming the Team}

A multidisciplinary team, ICU bundle champions, was formed to ensure a successful change project implementation. The team was composed of ICU RN champions (charge nurses and frontline staff), the ICU physicians, respiratory therapists, physical therapists, occupational therapist, and dietician. This step addresses the question: what are we trying to achieve? A Doctor of Nursing Practice (DNP) student invited the key stakeholders and the ICU bundle champions for a two- hour PowerPoint presentation of the project description and scope. Another meeting was conducted with the members of the ICU bundle champions to discuss roles, responsibilities, timelines, and milestones to clarify expectations and establish accountability. The team decided their preferred methods of communication during the meeting to ensure consistent updates on the progress of the project, to prevent miscommunications, confusion, and unnecessary delays. The DNP student demonstrated strong leadership and motivational skills to 
inspire and influence the team members. To accomplish these goals, the DNP student was available to guide and direct the staff, listen, and be open to team members' suggestions.

\section{Setting Aims}

This step in the model focuses on describing the specific time frame to measure achievement of specific outcome and process measures to determine if the change is an improvement. A project timeline is essential in setting and achieving the goals of the project. The tasks, assigned personnel, and allotted time frame are outlined in the project timeline. The discussion of the project timeline with the team members is critical to ensure timely achievement of assigned tasks. The project timeline started with securing an Evidence-Based Review Council approval from the University and the facility by the DNP student on February 12, 2020. The CNO, ICU Director, and the DNP student then met with the key stakeholders virtually to discuss project scope. The ICU bundle champions were to assist, monitor, audit, and provide ongoing bedside support and constructive feedback to the staff. Project implementation commenced on April 1, 2020 after completing staff training conducted virtually via Zoom meetings. Objectives of the PowerPoint presentation utilized for staff training is provided in Appendix F.

Data collection and analysis by the DNP student followed after concluding the project implementation. A reputable statistician from a local college was consulted and provided the DNP student with expert guidance with data analysis. A peer review on the project results was sought prior to the dissemination of the results. The DNP student disseminated the projects results to key stakeholders locally and nationally from July 1, 2020 to September 30, 2020. The project timeline is provided in Appendix G.

\section{Establishing Measures}


The DNP student virtually presented specific outcome and process measures to the ICU bundle champions and key stakeholders in evaluating improvement. Achievement of a goal of $10 \%$ or more reduction in the baseline incidence rate and the number of patients with severe stages of pressure injuries newly developed, along with a $90 \%$ or higher staff compliance with all bundle components signified improvement. ICU RN champions monitored, audited, and provided constructive feedback to staff to ensure bundle components are properly implemented.

\section{Selecting Changes}

The changes selected for the project include the implementation of individual pressure injury preventive strategies collectively and consistently implemented as a bundle to prevent PIs. The ICU bundle champions was employed to leverage the team member's expertise in monitoring, auditing, and providing ongoing bedside support and constructive criticisms to the staff using a compliance checklist. Additionally, staff education and training was incorporated as a component of the bundle implementation.

\section{Testing Changes}

The PDSA cycle was utilized to evaluate the effect of the bundle in the incidence of PIs in adult ICU patients. The team planned, observed, monitored, observed, audited, and provided feedback to the staff to determine compliance with bundle components. Lessons learned with the PDSA cycles were discussed and incorporated in the next cycle to resolve the barriers identified. Identified barriers for the project include lack of visible ICU leadership and engagement, staff compliance to the bundle components; nurse turnover; unavailability of pressure injury preventive supplies, and COVID-19 restrictions prohibiting the presence of the DNP student in the clinical site. The utilization of the ICU bundle champions and the provision of weekly updates and instructions virtually by the DNP student allowed the identification and resolution of 
the problems. The ICU RN champions monitored and provided ongoing bedside support and constructive feedback to the staff.

\section{Implementing Changes}

The implementation of the bundle in the ICU of a South Texas hospital required financial resources, supplies, and manpower. Additionally, the ICU staffing was closely examined to provide the manpower resources to implement the project. An estimated budget of $\$ 7,500.00$ was set for the project. The budget for the project is outlined in Appendix H.

The implementation of a pressure injury prevention bundle commenced after completing the staff training. The ICU bundle champions monitored, audited, and provided ongoing bedside support and constructive criticisms to the staff to ensure proper bundle implementation and staff compliance. Employing the ICU bundle champions was crucial to increase staff engagement.

\section{Spreading Changes}

Project results were shared locally after results were peer reviewed. The DNP student utilized different methods to disseminate the results. The methods employed comprised of a 30minute PowerPoint presentation with the key stakeholders thru a Zoom meeting; a short 10minute discussion of results during an ICU Department virtual meeting; updates through huddle boards posted in the ICU and during ICU grand rounds; and virtual presentation during a regular pressure injury committee meeting. Nationally, I plan to submit a manuscript proposal for possible publications in the American Journal of Critical Care and Critical Care Nurse journals as the results of the project are relevant to the contextual settings of these journals

\section{Project Evaluation}

Project evaluation is vital to determine success. The evaluation process consists of identifying, monitoring, and measuring the outcomes and goals to determine project success 
upon completion (My Management Guide, 2011). Further, evaluation provides valuable information as to why and how the project goals were achieved and how resources were efficiently utilized in the project (Levine, n.d.).

Initial planning and project management effectively minimized and controlled extraneous variables. Auditing, monitoring, and providing ongoing feedback and bedside support to staff ensured that the independent variable of implementing a pressure injury preventive bundle in the adult ICU patients directly caused the intended change of reducing the incidence of pressure injuries. Evaluation strategies utilized before, during, and after the project implementation will be discussed in the succeeding sections.

\section{Sample Population}

The DNP student, after reviewing the participants' EHR, selected the participants for the project. Adult ICU patients 18 years and older with a Braden score of 16 or less and who did not have any PIs upon admission to the ICU in April and May 2020 were included as participants. Thirty participants were included in the project and were tracked until they were transferred to other units or facilities, is discharged, dies, or had been in the ICU for at least 30 days. Pediatric patients admitted to the ICU were excluded from the project.

Demographic data were collected to describe the participants in the project. Data collected include age, gender, admitting diagnosis, body mass index (BMI), Braden scores, and length of ICU stay in days. Data obtained were organized and presented utilizing frequency and percentage distribution figures.

Figure 1 contains the frequency and percentage distribution of participants by age group. Each participant was classified in an age group based on their actual age. Each age group was bracketed by a range of 13 years. The total number of participants was also indicated in the 
figure. Blue bars signify frequency and orange bars signify the percentage. The mean, median and standard deviation were calculated based on the participants' age group.

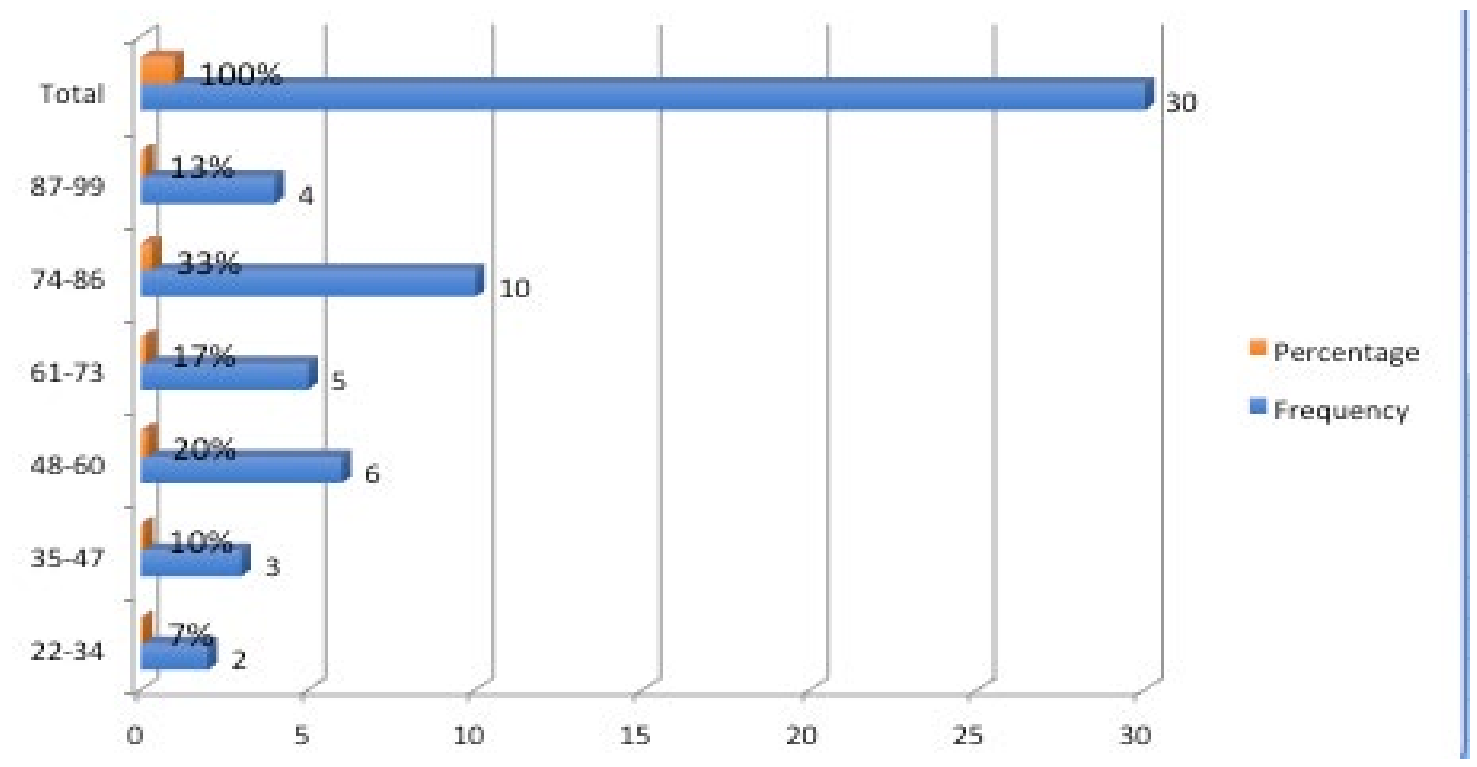

Figure 1. Describes frequency and percentage distribution of participants by age group.

As indicated in figure 1, 10 participants (33\%) of the sample belonged to the $74-86$ age group; six participants (20\%) of the sample belonged to the $48-60$ age group; five participants (17\%) of the sample belonged to the 61 - 73 age group; four participants $(13 \%)$ of the sample belonged to the 87 - 99 age group; three participants (10\%) of the sample belonged to the $35-$ 47 age group; and the remaining two participants (7\%) of the sample belonged to the $22-34$ age group. The youngest participant was 22 years old and the oldest was 98 years old. There were a total of 30 participants. The calculated mean age was 67.1 , median was 69.5 , and standard deviation was 19.96.

Figure 2 displays the participants' frequency and percentage distribution by gender. Each participant was categorized as either male or female. The total number of participants was also included in the figure. Blue bars indicate frequency and orange bars indicate the percentage of the overall group. The mean, median, and standard deviation for each gender were calculated and 
included in the data analysis.

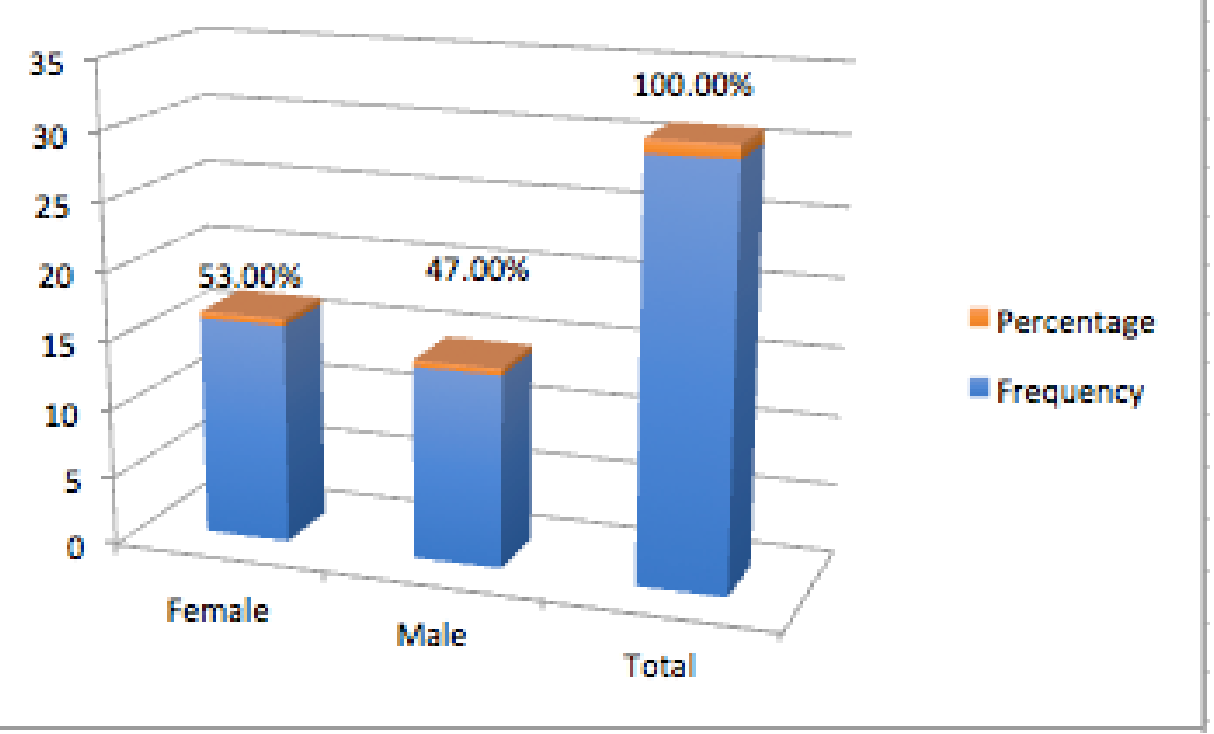

Figure 2. Shows frequency and percentage distribution of participants by gender.

As revealed in figure 2, 16 participants (53\%) of the sample were female while 14 participants $(47 \%)$ of the sample were male. There were a total of 30 participants. Mean, median, and standard deviation for the female participants were $71,75.5$, and 16.39 respectively. For the male participants, mean was 62.64, median was 64.5 , and standard deviation was 23.2

Figure 3 reflects the frequency and percentage distribution of the participants according to their BMIs. The participants were classified as underweight, normal, overweight or obese based on their actual BMIs. Blue bars represent frequency and the orange bars represent percentage of the overall group. There were a total of 30 participants. The mean, median, and standard deviation were calculated based on the BMIs collected from the participants. 


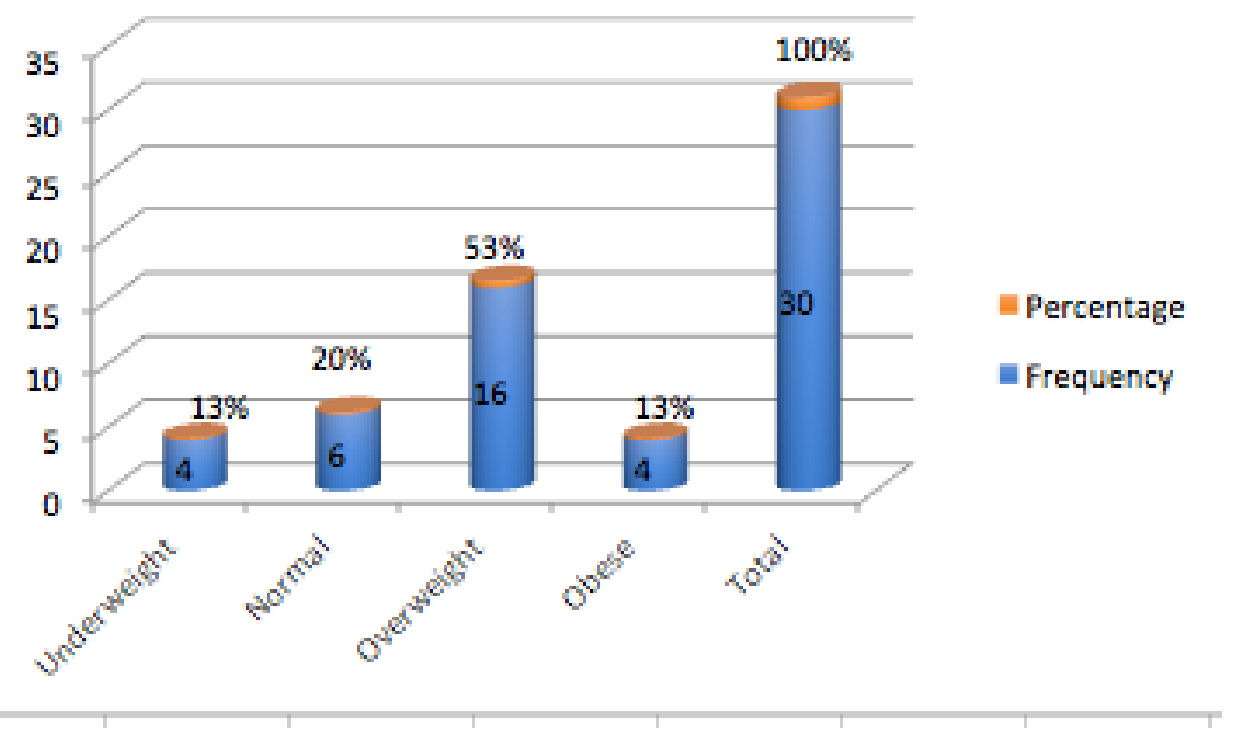

Figure 3. Depicts frequency and percentage distribution of participants by BMI.

As reflected in figure 3, 16 participants $(53 \%)$ of the sample were classified as overweight based on their BMIs; six participants (20\%) of the sample were categorized under the normal category; four participants $(13 \%)$ of the sample were underweight; and the remaining four participants $(13 \%)$ of the sample were categorized as obese. Actual BMIs revealed that the lowest recorded BMI was 14.47 and the highest was 41.57. There were a total of 30 participants. The calculated mean was 26.64, median was 27.53, and standard deviation was 6.25.

Figure 4 presents the participants' distribution according to their diagnoses upon admission in the ICU. The admitting diagnoses are represented in different shades. Light blue shade represents cardiovascular diagnosis, orange shade represents gastrointestinal, gray shade represents neurologic, gold shade represents respiratory, blue shade represents trauma, and green shade represents trauma resulting in neurological conditions. 

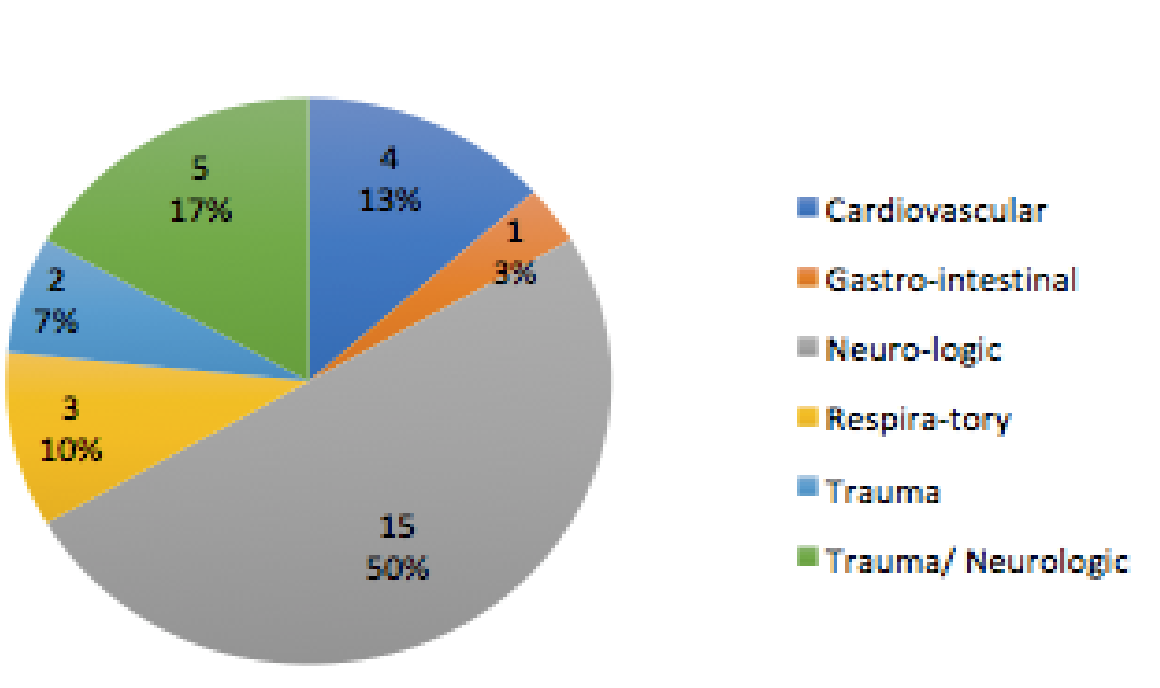

Figure 4. Indicates frequency and percentage distribution of participants by diagnoses.

As presented in figure 4, 15 participants $(50 \%)$ of sample were admitted in the ICU because of neurologic conditions; five participants (17\%) of the sample were admitted because of trauma that resulted in neurologic conditions. There were four participants (13\%) of the sample who had cardiovascular diagnoses; three participants $(10 \%)$ of the sample had respiratory diagnoses; two participants (7\%) of the sample were admitted because of trauma; and one participant $(3 \%)$ of the sample was admitted because of gastrointestinal condition. There were a total of 30 participants.

Figure 5 reveals the participants' frequency and percentage distribution by their length of stay in the ICU. The length of stay starts upon admission to the ICU until patient is transferred out of the unit, is discharged, or dies. The length of stay was measured in days and bracketed by a range of 9 days. Blue bars indicate frequency and orange bars indicate percentage. The mean, median, and standard deviation were calculated based on the data included in the table. 

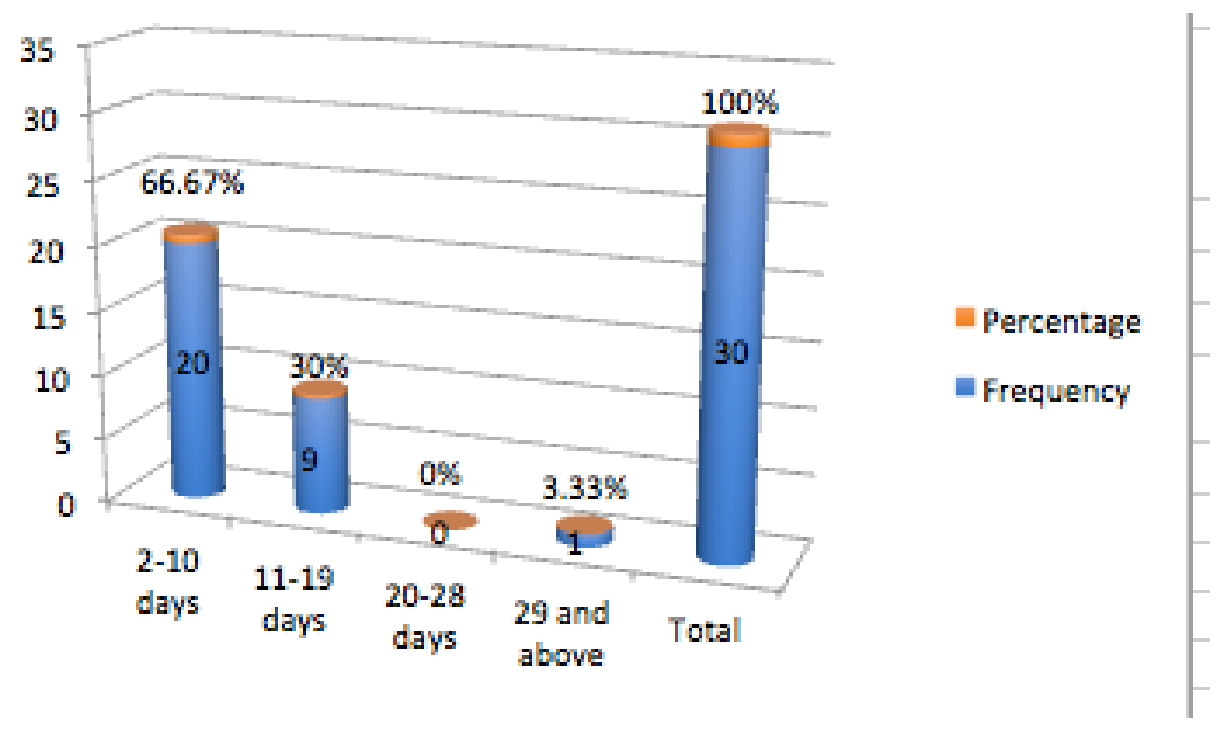

Figure 5. Shows frequency and percentage distribution of participants by the length of stay.

As revealed in figure 5, 20 participants $(66.67 \%)$ of the sample stayed in the ICU for 2-10 days; nine participants (30\%) of the sample stayed for 11-19 days; and the remaining one participant $(3.33 \%)$ of the sample stayed for 29 days or more. The actual length of stay reported in days revealed that the shortest length of stay in the ICU was two days and the longest was 30 days. There were a total of 30 participants. The mean was 8.21 , median was 7.95 , and the standard deviation was 5.81 .

Figure 6 depicts the stages of PIs observed at baseline, in April 2020, and May 2020. Blue bars signify baseline data, orange bars signify stages of PIs observed in April 2020, and gray bars signify stages of PIs observed in May 2020. Data at baseline were compared to data collected post pressure injury preventive bundle implementation. 


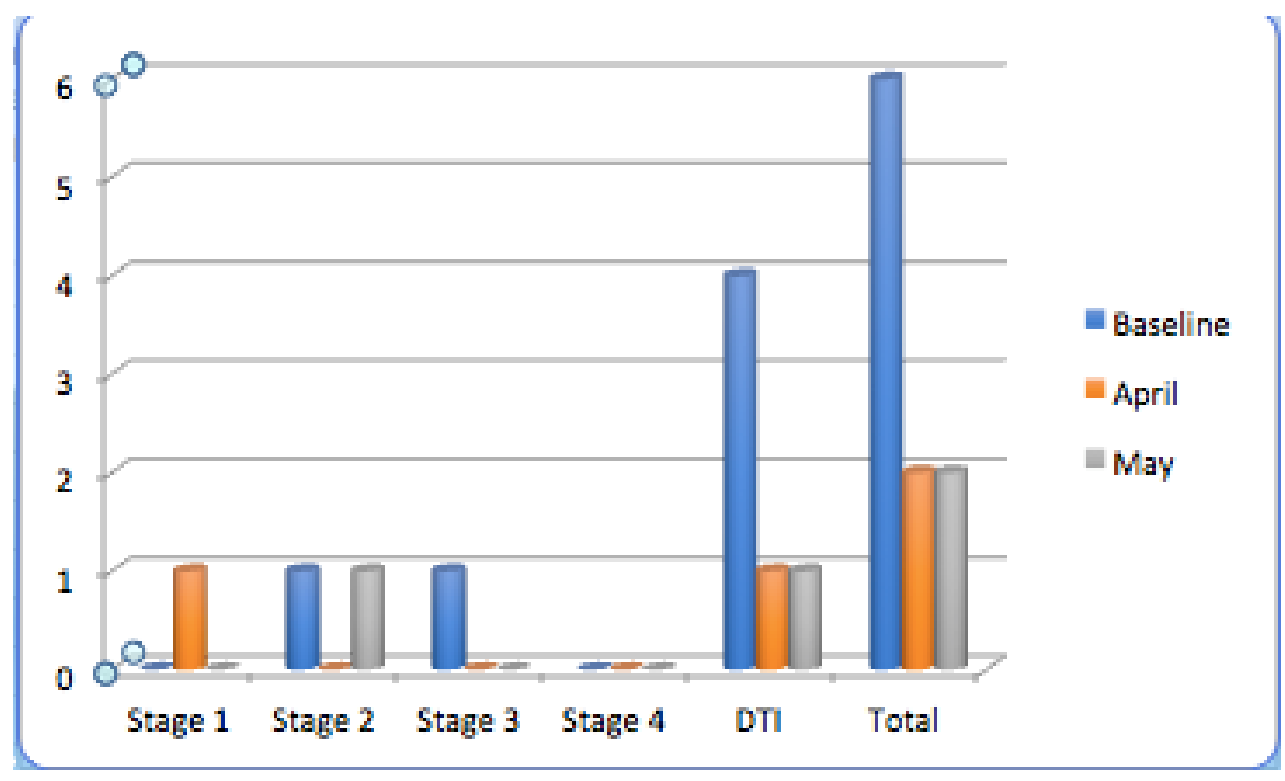

Figure 6. Depicts stages of PIs observed at baseline, in April 2020, and May 2020.

As depicted in figure 6, one patient had developed a stage two PI; one patient developed a stage three PI; and four patients developed deep tissue injury (DTI) according to the baseline data. Total incidence of PIs at baseline was six. Post-implementation data collected in April 2020 revealed one participant had developed a stage one PI and one participant developed a DTI. Total incidence was two for April 2020. Post-implementation data collected in May 2020 indicated one participant had developed a stage one PI and one participant had developed a DTI. The total incidence of PIs post-bundle implementation was four. The total incidence post-implementation revealed a reduction from the baseline. There was also a reduction in the severity of PIs developed post-implementation. None of the participants included in the project developed any stage three PIs after the pressure injury preventive bundle was implemented.

\section{Summative Evaluation}

The project aimed to evaluate the effect of implementing a pressure injury preventive bundle in reducing the incidence of PIs in adult ICU patients. A data collection form was prepared and carefully reviewed by the DNP student to ensure completeness, accuracy, and 
avoidance of duplication or missing data. The data collection form had two parts. The first part addressed the participants' descriptive data that included admission date, age, sex, BMI, diagnosis, length of stay (days) in the ICU, Braden risks scores, incidence of PIs along with the stages and location of the PIs. Descriptive data were included to provide useful contextual information when interpreting results.

The second part of the data collection form served as a compliance checklist. This checklist specified staff compliance on twice a day documentation of Braden scores; compliance with turning the patients every two hours; securing a nutritional consult; compliance with twice a day documentation in using protective devices applied to the sacral area, bilateral heels, and body parts where a medical device is; compliance with twice a day documentation in using air mattresses on top of regular mattresses; and compliance with staff education on bundle implementation. The compliance checklist is an essential tool in auditing, monitoring, and providing ongoing constructive feedback to the ICU staff. A sample of the data collection form is provided in Appendix I.

Data collection commenced after securing approval from the university’s Evidence Practice Review Council (EPRC) and from the facility's Chief Executive Officer (CEO). A copy of the letter of approval from the EPRC and facility's CEO are provided in Appendix K and Appendix L. Obtaining approval was necessary prior to project implementation to ensure compliance with the ethical standards outlined in the1975 Helsinki Declaration. Data collection was briefly interrupted as COVID- 19 restrictions were implemented prohibiting the DNP student's presence in the clinical area. However, upon the recommendation of the Chief Nurse Officer (CNO), the DNP student was issued a facility authorized laptop and granted temporary access to use the laptop to retrieve and collect data remotely from the participants' EHR 7, 14, 
21, 30, and 60 days post bundle implementation. The laptop was password protected and was kept in a locked drawer when not directly in use.

A patient list was created for the EHR to facilitate ease in tracking the participants. Results of weekly audits on staff compliance were provided to the ICU RN champions through emails, phone conversations, and text messages. The weekly updates included specific instructions for the ICU champions to focus on as they monitored and provided ongoing bedside support to the staff. Compliance with the education component was based on the attendance obtained during the virtual training. Data on incidence was obtained from the wound care nurses every Wednesday. Data provided on incidence were then validated through a review of staff documentation on incidence, stage, and location of PIs in the patients' EHR.

Hard copy data were kept in a folder stored and secured in a locked drawer in a locked office. A Microsoft Excel spreadsheet was created to store electronic data on a laptop with strong password protection. The laptop was stored in a locked desk drawer when not in use. An identification number was assigned to each participant to de-identify data collected. The identification number comprised of the letter " $A$ " for participants obtained in April 2020, and “M” for May 2020 participants along with the last two numbers depicting the participants' room number and medical record number. There were no missing data noted upon the completion of data evaluation. The hardcopy data will be shredded beyond reclamation upon the completion of the DNP degree.

\section{Formative Evaluation}

The primary outcome measure is a $10 \%$ or more reduction in the incidence rate of pressure injuries (PIs) along with a secondary outcome measure of reducing the severity of PIs newly developed after two months of the pressure injury preventive bundle implementation. 
Incidence rate refers to the total number of new cases of PIs in adult ICU patients at a given time multiplied by 100 and divided by the total number of ICU patients in the same given time. The incidence is a valid and feasible measurement of the effectiveness of pressure injury prevention strategies (Gill, 2015).

Data on primary outcome measure were collected 30 and 60 days post preventive bundle implementation by the DNP student. Post implementation data collected were compared to February 2019 baseline data on incidence and severity of PIs developed. The severity of the newly developed PIs were classified as stage one, two, three, four, unstageable, DTI, and medical-related pressure injury as per the guidelines from the European Pressure Ulcer Advisory Panel and National Pressure Ulcer Advisory Panel (2009).

The DNP student conducted a two-hour meeting with the ICU RN champions and the CNO through WEBEX prior to project implementation. The initial meeting was utilized to present the project's description, scope, timelines along with roles and responsibilities. Upon completion of the initial meeting, the remaining ICU nurses were given one hour training through Zoom. Multiple Zoom meeting schedules were emailed and texted to the staff a week before the training to enable the staff to choose a convenient time for them to participate in the virtual training. Reminders were sent via text messaging a day prior to the scheduled virtual meeting to confirm attendance and ensure higher compliance rate with the bundle training. The DNP student encountered challenges in eliciting and increasing staff engagement with the bundle implementation during the first month of implementation. Reasons for the difficulty chiefly stemmed from the enforcement of multiple COVID-19 pandemic restrictions and guidelines throughout the hospital. A follow up Zoom meeting was conducted with the ICU RN champions 
a month post implementation to provide updates, motivate staff to increase engagement, and remind the ICU champions of the project's vision and mission.

Staff compliance with all six components of the bundle implementation constituted the project's process measures. The project aimed to achieve a $90 \%$ or higher compliance with all components of the bundle implementation. Staff compliance was audited weekly to ensure treatment fidelity. The weekly audits on the process measures allowed the DNP student to provide instructions and updates virtually to the ICU RN champions as they monitored, and to provide ongoing constructive feedback to the ICU staff.

Additionally, the project's process measures were also considered as the project's sustainability measures. The ICU bundle champions need to continue the process of auditing and monitoring staff compliance with the components of the bundle. The continued use of the compliance checklist is essential in producing sustained long-term positive pressure injury outcomes post implementation. Other sustainability measures included incorporating the components of the bundle in the nurses' workflow in the EHR documentation, including the bundle education on annual staff education and performance evaluation, and embedding the bundle education in the newly hired staff during orientation

Balancing measures included the costs for training the ICU staff, costs for procuring pressure injury preventive supplies, and costs for staff incentives (free meal tickets). Upon the completion of the project, $\$ 4,239.50$ was spent on staff training, $\$ 1,650$ was spent for supplies, and $\$ 350$ was spent for free meal tickets awarded to the staff as incentives for their compliance and engagement. The DNP student was responsible for monitoring and ensuring that the expenses remained within the budget. Additional balancing measures included collaborating with the ICU Director and clinical supervisors to ensure adequate staffing along with coordinating 
with the unit's supplies personnel to ensure availability of pressure injury preventive supplies in the unit.

Treatment costs and cost savings were the project's financial measures. The treatment costs consisted of adding the costs resulting from multiplying the number of PIs newly developed by the national average costs of treating the specific stage of PIs in a given time. The cost savings were calculated and estimated by deducting the treatment costs at a given time from the baseline costs of treatment. Using baseline data, baseline treatment costs were estimated at $\$ 315,580$ with cost savings post implemented estimated at $\$ 217,220$.

\section{Statistician}

A reputable statistician employed at a local college agreed to provide needed assistance and guidance in the choice and application of statistical tests for data analysis. Upon request, a Microsoft Excel spreadsheet containing the data collected was created and emailed to the statistician. The DNP student employed several methods in collaborating with the statistician. These methods include emails, phone conversations, and text messaging.

\section{Data Analysis}

Descriptive statistics consisting of frequency, percentage, mean, median, and standard deviation were utilized to describe and organize quantitative data. Data collected were classified as continuous or nominal variables. Appendix $\mathbf{J}$ is provided as a data analysis table describing each variable.

The z-test, an inferential statistical test, was utilized to evaluate the effect of the bundle implementation on reducing the incidence of PIs in adult ICU patients. A $p$ value $=.05$ was used as the criteria in determining statistical significance of an improvement and what is clinically meaningful improvement post implementation. 
Baseline incidence rate for PIs was $20.67 \%$ and was reduced to $13.3 \%$ post bundle implementation. The $7.37 \%$ reduction was lower than a set goal of $10 \%$. The reduction indicated an improvement from baseline. However, the calculated $\mathrm{z}$ value $=-0.99$ that has a corresponding $\mathrm{p}$ value $=0.1611$ was greater than $\mathrm{p}$ value $=0.05$. This result signified that the reduction in the incidence of PIs in adult ICU patients post implementation was not statistically significant.

Locations of PIs newly developed were not specified in the baseline data. Hence, comparison on the location of newly developed PIs post implementation was not possible. The post implementation data indicated that one participant developed a stage one on the right cheek; one participant developed a stage two on the right buttock; and two participants developed DTIs on the sacral and coccyx respectively. Further, data revealed a reduction in the number and severity of the newly developed PIs post implementation. The reduction was evidenced by the absence of a stage three PI and less number of DTIs developed after the pressure injury prevention bundle was implemented.

Data collected on staff compliance with the bundle components yielded a $93.63 \%$ compliance with the documentation of Braden Score; $71.12 \%$ compliance with turning every two hours; $95.45 \%$ compliance with securing nutritional consultation; $90.4 \%$ compliance with using protective dressings; $95.45 \%$ compliance with using air vented mattresses; and $97.75 \%$ compliance with bundle training. The findings signified achievement of a $90 \%$ or higher compliance in five out of six bundle components. Compliance with turning has the lowest reported percentage at $71.12 \%$, supporting previously reported findings that turning every two hours remained to be the most difficult component to accomplish (Anderson et al. (2015). According to Richardson et al. (2017), the difficulty stemmed from the patients' instability while Carino et al. (2012) posited that the challenge was related to the very strict definition of success 
in achieving this particular component. Turning every two hours has remained as a standard pressure injury prevention strategy for critically ill patients (Amr et al., 2017; Carino et al., 2012; Richardson et al., 2017) and is associated with a significant reduction of PIs in adult ICU patients when incorporated in the bundle implementation (Coyer et al., 2015; Tayyib et al., 2016).

\section{Discussion and Implications}

The primary outcome finding from the implementation of a pressure injury preventive bundle was the $13.3 \%$ incidence or a $7.37 \%$ reduction in the incidence of PIs in adult ICU patients after two months. The global incidence of PIs in adult ICU patients ranges from $3 \%-50 \%$. Although the reduction in incidence was not statistically significant, the findings indicated a clinically meaningful improvement on pressure injury outcomes postimplementation. The results were comparable with the reports published on the effect of bundle implementation in reducing the incidence of pressure injuries in adult ICU patients.

The practice change was not implemented as planned. COVID-19 restrictions prevented the DNP student from being present at the clinical site. Creating the momentum needed to propel the project implementation to the next phases was perplexing during a pandemic situation. However, given the pandemic restrictions, the DNP student creatively devised a plan to utilize technology, phone conversations, emails, and text messages to increase staff awareness and engagement during the project implementation.

Process measures for the project consisted of staff compliance with the six components of the pressure injury preventive bundle. The six components included the use of Braden score; turning the patients every two hours; obtaining nutritional consults; application of protective dressings to the sacrum, heels, and other body parts where a medical device is in use; the use of air vented mattresses on top of regular mattresses; and staff education on the bundle 
implementation. Staff compliance was audited weekly post-implementation to ensure treatment fidelity and production of the desired outcome. Additionally, the weekly audits on compliance aided the DNP student in providing timely and constructive feedback to the ICU champions. The ICU champions were instructed to monitor and provide ongoing bedside support and feedback to the staff. Staff compliance was $90 \%$ and above with 5 out of the 6 bundle components. Compliance on turning every two hours was at $71.12 \%$. The results supported other published literature reviewed.

Achieving a higher compliance in turning patients every two hours has remained to be the most challenging undertaking. Turning adult ICU patients every two hours requires physical manpower. The needed manpower and workload demands of caring for the adult ICU patients were not adequately supported by the unit's staffing patterns. For other nurses, turning was not a priority because the patients' need for hemodynamic stability was prioritized over repositioning every two hours. Implications of the process measures include a recommendation to carefully examine staffing in the ICU to provide the physical manpower to assist the nurses in achieving a higher compliance rate in turning. Another implication is for providing visible unit leadership to the staff to increase engagement and accountability.

The absence of the DNP student in the clinical site made it more vital to effectively utilize the ICU champions. Through consistent communication and virtual updates, the DNP student motivated, encouraged, and reminded the ICU champions of the projects' vision and emphasized the importance of their roles as the project implementation advanced. The consistent communication and virtual updates were helpful in increasing staff engagement.

Reducing the incidence of PIs in adult ICU patients implied clinical improvement postimplementation. Ensuring the treatment fidelity by weekly auditing, monitoring, and providing 
constructive feedback to ICU champions and staff increased the likelihood of implementing the intervention appropriately. Thus, the project yielded positive PI related outcomes in adult ICU patients.

Limitations of the project included a reduced number of participants for the project. There were only 30 participants in the project. The statistician recommended at least 83 participants to support a statistically significant reduction in the incidence of PIs from baseline. The recommendation implied that the project had to be implemented for more than two months to have the recommended number of participants in the project. However, despite the limited number of participants, the findings of the project indicated a reduction in incidence, signifying an improvement post-implementation.

Another limitation of the project was the pandemic situation brought about by COVID-19 during the project implementation. The pandemic restrictions brought unprecedented demands to the ICU leadership as well as the staff. There was no visible leadership support from the ICU leadership as their roles shifted to ensuring safety to the staff while the staff dispensed their daily functions during the pandemic. The pandemic restrictions prevented the presence of the DNP student in the clinical site during the project implementation, thus requiring reliance on the ICU RN champions to monitor and provide bedside support to the staff. The reliance meant an increased workload for the already stressed nurses coping with the pandemic. The ICU staffing during the pandemic also reduced the availability of physical manpower needed to achieve higher compliance with turning every two hours. Also, the limited supply of personal protective equipment prevented most of the ICU champions from assisting other staff in the turning.

Suggestions for next steps consisted of incorporating the practice change into new ICU employee orientation and annual competency/training programs. Another suggestion is 
embedding the bundle components in the EHR nurse workflow documentation of PI preventive strategies. It would be helpful to conduct the project in another ICU setting, especially with the lesser COVID-19 restrictions in place, and to evaluate the content of ongoing staff education to increase staff awareness and engagement.

The take-home message from this project was to know what resources are available and creatively utilize the resources to reduce the incidence of pressure injuries in adult ICU patients. The collaboration with a faculty advisor and preceptor during implementation was necessary to devise strategies in dealing with unanticipated situations.. Having a clear vision of the project's vision and mission and being resilient can significantly help in mitigating unforeseen situations and still yield positive outcomes from implementing a change project.

\section{Dissemination}

An evaluation of the strengths, weaknesses, and opportunities was conducted as part of the project closure. Peer reviews of the project results were conducted prior to sharing the results. The peer reviews included constructive feedback from the faculty advisor, preceptor, writing center coach, and statistician. Comments and constructive feedback were thoughtfully considered and incorporated in the final project. Baseline and outcome findings were included in the project's outcome.

Initially, a short PowerPoint presentation was used to communicate results with the CNO, ICU Director, and ICU clinical supervisors. This was followed by a 10-minute Zoom presentation with the ICU staff during a staff meeting. Internally, results were shared during a monthly pressure injury committee meeting. The pressure injury committee consists of CNOs, ICU directors, clinical supervisors, a risk management director, a quality improvement director, a 
senior health informatics analyst, an education director, selected frontline staff, and wound care nurses.

Externally, the American Journal of Critical Care and Critical Care Nurse Journal are targeted for possible publication. The project results are relevant to improving patient outcomes in these contextual settings. The paper will also be submitted in full text to SOAR@USA to fulfill DNP program requirements. SOAR@USA is an institutional repository that will improve the availability and discoverability of the DNP project. Finally, the project will be submitted to the Virginia Henderson Global Nursing e-Repository to facilitate worldwide dissemination of the DNP project information.

\section{Conclusion}

The paper aimed to evaluate the effect of a pressure injury prevention bundle implementation on the incidence of PIs in adult ICU patients at a South Texas hospital after a two-month period. PIs are significant healthcare problem, especially in adult ICU patients who have high risk for PI development. Theories and evidence support the effectiveness of the ICU staff implementing a pressure injury preventive bundle, along with a multidisciplinary approach, audit, and feedback in significantly reducing the incidence of PIs in adult ICU patients. A high staff compliance rate achieved on all bundle components will lead to a successful bundle implementation and improved pressure injury outcomes, especially the reduced number and severity of newly developed PIs. The findings did not show statistical significance in the reduction. However, the project result demonstrated that implementing a pressure injury preventive bundle reduced the incidence and severity of PIs in adult ICU patients signifying clinically improving pressure-injury outcomes. These outcomes are in alignment with the 
hospital's vision and mission of providing the highest quality of care for patients and their families. 


\section{References}

Amr, A., Yousef, A., Amirah, M., \& Alkurdi, M. (2017). A pre-post study evaluating the effectiveness of a new initiative, the "PRESSURE Bundle," compared with standard care in reducing the incidence and valence of sacral pressure ulcers in critically ill patients in an intensive care unit in Riyadh, Saudi Arabia. Saudi Critical Care Journal, 1(3), 75. doi:10.4103/sccj.sccj29_17

Anderson, M., Guthrie, O., Kraft, W., Reicks, P., Skay, C., \& Beal, A. (2015). Universal pressure ulcer prevention bundle with Wound Ostomy Continence nurse support. Journal of Wound, Ostomy, and Continence Nurses Society, 42(3), 217-225. doi:10.1097/WON.000000000000.109

Australian Wound Management Association (2012). Pan pacific clinical practice guidelines for the prevention and management of pressure injury. Abridged version. Osborne Park, WA, Australia: Cambridge Publishing.

Ayello, E. A., \& Braden, B. (2002). How and why to do pressure ulcer risk assessment. Advances in Skin \& Wound Care, 15(3), 125-131. doi:10.1097/00129334-20020500000008

Berlowitz, D. (2014). Incidence and prevalence of pressure ulcers: In D. R Thomas \& G. A. Compton (Eds.) Pressure ulcers in the aging population: A guide for clinicians. New York: NY: Springer

Byrne, J., Nichols, P., Sraczynski, M., Stelmaski, L, Stetzer, M., Line, C., \& Carlin, K. (2016). Propylactic sacral dressing for pressure ulcer prevention in the high -risk patients. American Association of Critical Care Nurses, 25(3), 228-234. doi: 10.4037/ajc2016979 
Carino, G.,Ricci, D., Bartula, D., Manzo, E., \& Sargent, J. (2012). The HAPU bundle: A tool to reduce the incidence of hospital-acquired pressure ulcers in the ICU. International Journal of Nursing Sciences, 2(4), 34-37. doi: 10.5923/j.nursing.20120204.02

Chan, W. S., Pang, S. M., \& Kwong, E. W. (2009). Assessing predictive validity of the modified Braden Scale for prediction of pressure ulcer risk of orthopaedic patients in an acute care setting. Journal of Clinical Nursing, 18(11), 1565-1573. doi:10.1111/j.13652702.2008.02757.x

Chicano, S. \& Drolshagen, C. (2009). Reducing hospital-acquired pressure ulcers. Journal of Wound, Ostomy, and Continence Nursing, 36(1), 45-50. doi:10.1097/01.WON.0000345175.51117.ca

Coyer, F., Gardner, A., Doubrovsky, A., Cole, R., Ryan, F. M., Allen, C., \& McNamara, G. (2015). Reducing pressure injuries in critically ill patients by using a patient skin integrity care bundle (InSPiRE). American Journal of Critical Care, 24(3), 199-209. doi:10.4037/ajcc2015930

Cuddigan, J. (2012). Critical care. In: B. Pieper (Ed.). Pressure ulcers: Prevalence, incidence, and implications for the Future. 2nd ed. Washington, DC: National Pressure Ulcer Advisory Panel.

Demarre, L., Van Lancker, A., Van Hecke, A., Verhaeghe, S., Gryhdonck, M., Annemans, L., \& Beeckmann, D. (2015). The cost of prevention and treatment of pressure ulcers: A systematic review. International Journal of Nursing Studies, 52(11), 1754-1774. doi: 10.1016/j.ijnurstu.2015.06.006.

DeOreo, P., Duval, L., Paul, R., Kodali, P., Rankin, L., Malony, D., . . Rosen, S. (2012). Medical Director Toolkit - ESRD Network Forum. Retrieved from 
http://esrdnetworks.org/resources/toolkits/mac-toolkits-1/medical-director$\underline{\text { toolkit/medical-director-toolkit }}$

Ebell, M. H., Siwek, J., Weiss, B. D., Woolf, S. H., Susman, J., Ewigman, B., \& Bowman, M. (2014). Strength of Recommendation Taxonomy (SORT): A patient-centered approach to grading evidence in the medical literature. The Journal of the American Board of Family Medicine, 17(1), 59-67. doi:10.3122/jabfm.17.1.59

European Pressure Ulcer Advisory Panel and National Pressure Injury Advisory Panel. (2009). Prevention of pressure ulcers: Quick reference guide. Washington DC: NPUAP.

George, J.B. (2011). Nursing theories-The base for professional nursing practice, 5th ed. Norwalk: Appleton \& Lange

Gill, E. (2015). Reducing hospital-acquired pressure ulcers in intensive care. British Medical Journal, 4(1), 2055-3015. doi: 10.1136/bmjquality. u205599 w3015

Gray-Siracusa, K. \& Schrier, L. (2011). Use of an intervention bundle to eliminate pressure ulcers in critical care. Journal of Nursing Care Quality, 26(3), 216-225. doi:10.1097/ncq.0b013e31820e11be

Grealy, B. \& Chaboyer, W. (2012). Essential nursing care of the critically ill patient. In: D. Elliot, D.Aitken, L. Chaboyer W.(Eds.). ACCCN's critical care nursing. 2nd ed. Sydney, Australia: Elsevier Mosby.

Harmer \& Henderson, V. (1995). Textbook of the principles and practice of nursing (5th ed.). New York: Macmillan.

Henderson, V. (1960). Basic principles of nursing care. London: International Council of Nurses. 
Hill Rom (2019). Report on MMC's Hospital-Acquired Pressure Injury by Unit. Retrieved from https://hillrom.com/

Horner, D. L. \& Bellamy, M. C. (2012). Care bundles in intensive care. Continuing Education in Anaesthesia Critical Care \& Pain, 12(4), 199-202. doi:10.1093/bjaceaccp/mks021

Institute for Healthcare Improvement (2019). Science of improvement: How to improve. Retrieved from http://www.ihi.org/resources/Pages/HowtoImprove/ScienceofImprovementHowtoImprov $\underline{\text { e.aspx }}$

Kalowes, P., Messina, V., \& Li, M. (2016). Five-layered silicone foam dressing to prevent pressure ulcers. American Journal of Critical Care, 25(6), 108-119. doi: 10.4037/ajc20168075

Langley, G. J., Nolan, K. M., Nolan, T., Norman, C., \& Provost, L. (2009). The improvement guide: A practical approach to enhancing organizational performance. San Francisco: Jossey-Bass.

Levine, R. (n.d.). Five Reasons why evaluation matters to your project. Retrieved from https://www.nichq.org/insight/5-reasons-why-evaluation-matters-your-project

Lyder, C. H., Wang, Y., Metersky, M., Curry, M., Kliman, R., Verzier, N. R., \& Hunt, D. R. (2012). Hospital-acquired pressure ulcers: results from the national Medicare patient safety monitoring system study. Journal of the American Geriatrics Society, 60(9), 16031608. doi:10.1111/j.1532-5415.2012.04106.

McAllen Medical Center (n.d.). About us. Retrieved from https://www.mcallenmedicalcenter.com/about-us 
McAllen Medical Center (2019). Featured Services. Retrieved from https://www.mcallenmedicalcenter.com/

McInnes, E., Jammali-Blasi, A., Bell-Syer, S. E., Dumville, J. C., \& Cullum, N. (2011). Support surfaces for pressure ulcer prevention. Retrieved from http://onlinelibrary.wiley.com/doi/10.1002/14651858.CD001735.pub4/abstract.

My Management Guide (2011). Project evaluation: The general guideline. Retrieved from https://mymanagementguide.com/project-evaluation-planning-the-general-guidelines/

National Pressure Ulcer Advisory Panel, European Pressure Ulcer Advisory Panel, \& Pan Pacific Pressure Injury Alliance. (2014). Prevention and treatment of pressure ulcers: Quick reference guide. Retrieved from http://www.npuap.org/wpcontent/uploads/2014/08/Updated-10-16-14-Quick-ReferenceGuide-DIGITAL-NPUAP-EPUAP-PPPIA-16Oct2014.pdf

Ober, S. \& Craven, G. (2008). Payment to hospitals for hospital-acquired conditions prohibited by CMS in 2008. Journal of Infusion Nursing, 31(3). doi:10.1097/01.nan.0000317698.74019. 51

Pokorny, M. (2014). Nursing theorists of historical significance. In In M.R. Alligood (ED.) Nursing theorists and their work (8th ed.). St. Louis, MO: Elsevier

Provost, L. (2019). Quality improvement in healthcare: Five guiding principles. Retrieved from https://www.healthcatalyst.com/insights/quality-improvement-healthcare-5-guidingprinciples

Robb, E., Jarman, B., Suntharalingam, G., Higgens, C., Tennant, R., \& Elcock, K. (2010). Quality improvement report using care bundles to reduce in-hospital mortality: Quantitative survey. British Medical Journal, 340(7751), 861-863. 
Richardson, A., Peart, J., Wright, S., \& Mccullagh (2017). Reducing the incidence of pressure ulcers in critical care units: a 4-year quality improvement. International Journal for Quality in Healthcare, 29(3), 433-439. doi: 10.1093/intqhe/mzx040

Roberts, S., Mcinnes, E., Wallis, M., Bucknall, T., Banks, M., \& Chaboyer, W. (2016). Nurses' perceptions of a pressure ulcer prevention care bundle: A qualitative descriptive study. Bio Medical Central Nursing, 15(1). doi:10.1186/s12912-016-0188-9

Santamaria, N., Gerdtz, M., Sage, S., McCann, J., Freeman, A., Vassiliou, T., . . Knott, J. (2015b). A randomized controlled trial of the effectiveness of soft silicone multi-layered foam dressings in the prevention of sacral and heel pressure ulcers in trauma and critically ill patients: The Border Trial. International Wound Journal, 12(3), 302-308. doi:10.1111/iwj.12101

Soban, L. M., Hempel, S., Munjas, B. A., Miles, J., \& Rubenstein, L. V. (2011). Preventing pressure ulcers in hospitals: A systematic review of nurse-focused quality improvement interventions. The Joint Commission Journal on Quality and Patient Safety, 37(6). doi:10.1016/s1553-7250(11)37032-8

Tayyib, N. \& Coyer (2017). Translating pressure ulcer prevention into intensive care nursing practice. Journal of Nursing Quality, 32(1), 6-14. doi: 10.1097/NCQ.0000000000000199

Tayyib, N., Coyer, F., \& Lewis, P. A. (2016). Implementing a pressure ulcer prevention bundle in an adult intensive care. Intensive and Critical Care Nursing, 37, 27-36. doi:10.1016/j.iccn.2016.04.005

Tayyib, N. \& Coyer, F. (2016). Effectiveness of pressure ulcer prevention strategies for adult patients in intensive care units. Joanna Briggs Institute Database of Systematic Reviews and Implementation Reports, 14(3), 35-44. doi:10.11124/jbisrir-2016-2400 
Tayyib, N., Coyer, F., \& Lewis, P. A. (2015). A two-arm cluster randomized control trial to determine the effectiveness of a pressure ulcer prevention bundle for critically ill patients. Journal of Nursing Scholarship, 47(3), 237-247. doi:10.1111/jnu.12136

Zuo, X. \& Meng, F. (2015). A care bundle for pressure ulcer treatment in intensive care units. International Journal of Nursing Sciences, 2(4), 340-347. doi:10.1016/j.ijnss.2015.10.0 


\section{Appendix A}

Summary of Primary Research Evidence

\begin{tabular}{|c|c|c|c|c|c|c|}
\hline Citation & Sample Size & $\begin{array}{l}\text { Design Level \& } \\
\text { Quality Grade }\end{array}$ & $\begin{array}{l}\text { Intervention \& } \\
\text { Comparison } \\
\text { Definitions }\end{array}$ & $\begin{array}{l}\text { Theoretical } \\
\text { Foundations }\end{array}$ & $\begin{array}{l}\text { Outcome } \\
\text { Definition }\end{array}$ & $\begin{array}{l}\text { Results- Key } \\
\text { Findings }\end{array}$ \\
\hline $\begin{array}{l}\text { Amr, A., Yousef, A., Amirah, M., \& } \\
\text { Alkurdi, M. (2017). A pre-post study } \\
\text { evaluating the effectiveness of a new } \\
\text { initiative, the "PRESSURE Bundle," } \\
\text { Compared with standard care in } \\
\text { reducing the incidence and prevalence } \\
\text { of sacral pressure ulcers in critically ill } \\
\text { patients in an intensive care unit in } \\
\text { Riyadh, Saudi Arabia. Saudi Critical } \\
\text { Care Journal, 1(3), 75. } \\
\text { doi:10.4103/sccj.sccj_29_7 }\end{array}$ & 660 & $\begin{array}{l}\text { Pre-post study } \\
\text { design } \\
\text { SORT } \\
\text { Level } 3\end{array}$ & $\begin{array}{l}\text { Pressure" bundle } \\
\text { prevention } \\
\text { measures that } \\
\text { consists of } \\
\text { positioning, risk } \\
\text { assessment, } \\
\text { elevation of heel, } \\
\text { skin assessment, } \\
\text { skincare and } \\
\text { protective } \\
\text { barriers, ultimate } \\
\text { nutrition, relief of } \\
\text { pressure, and } \\
\text { elevation of } \\
\text { head }<30 \text { degrees }\end{array}$ & $\begin{array}{l}\text { Not indicated, } \\
\text { however it } \\
\text { appears that the } \\
\text { authors may have } \\
\text { adapted the } \\
\text { holistic theory } \\
\text { whereby the } \\
\text { whole is more } \\
\text { than the sum of its } \\
\text { parts }\end{array}$ & $\begin{array}{l}\text { Incidence- the } \\
\text { number of new } \\
\text { cases of pressure } \\
\text { injuries that } \\
\text { developed in adult } \\
\text { ICU patients at a } \\
\text { given time } \\
\text { Prevalence- the } \\
\text { number of new } \\
\text { and existing } \\
\text { pressure injuries } \\
\text { in adult ICU } \\
\text { patients at a given } \\
\text { time }\end{array}$ & $\begin{array}{l}\text { Significant } \\
\text { reduction in the } \\
\text { incidence in } 2 \\
\text { months compared } \\
\text { with standard care } \\
\text { group prevalence } \\
\text { of sacral ulcers }\end{array}$ \\
\hline $\begin{array}{l}\text { Anderson, M., Guthrie, P., Kraft, W. } \\
\text { Reicks, P., Skay, C, \& Beal, A.L. } \\
\text { (2015). Universal pressure ulcer } \\
\text { prevention bundle with wound ostomy } \\
\text { continence nurse (WOC). Journal of } \\
\text { Wound, Ostomy, and Continence } \\
\text { Nursing, 42(3), 217-225. doi: } \\
\text { 10.1097/WON.000000000000109 }\end{array}$ & 327 & $\begin{array}{l}\text { Quasi- } \\
\text { experimental, } \\
\text { pre- and post- } \\
\text { intervention } \\
\text { SORT } \\
\text { Level } 3\end{array}$ & $\begin{array}{l}\text { Universal } \\
\text { Pressure Ulcer } \\
\text { Prevention Bundle } \\
\text { (UPUPB) } \\
\text { combined with } \\
\text { proactive, semi- } \\
\text { weekly WOC } \\
\text { nurse rounds }\end{array}$ & $\begin{array}{l}\text { Not indicated, } \\
\text { although Virginia } \\
\text { Henderson's Need } \\
\text { theory can be a } \\
\text { good fit for the } \\
\text { study }\end{array}$ & $\begin{array}{l}\text { Incidence- new } \\
\text { cases of pressure } \\
\text { ulcers that } \\
\text { developed in ICU } \\
\text { patients }\end{array}$ & $\begin{array}{l}\text { Statistically } \\
\text { significant and } \\
\text { clinically relevant } \\
\text { reduction in the } \\
\text { incidence of } \\
\text { pressure ulcers }\end{array}$ \\
\hline
\end{tabular}




\begin{tabular}{|c|c|c|c|c|c|c|}
\hline $\begin{array}{l}\text { Carino, G.,Ricci, D., Batula, } \\
\text { D., Manzo, E., \& Sargent, J. } \\
\text { (2012). The HAPU bundle: A } \\
\text { tool to reduce the incidence of } \\
\text { hospital-acquired pressure } \\
\text { ulcers in the ICU. } \\
\text { International Journal of } \\
\text { Nursing Sciences, 2(4), 34-37. } \\
\text { doi: } \\
\text { 10.5923/j.nursing.20120204.02 }\end{array}$ & 169 & $\begin{array}{l}\text { Pre and post } \\
\text { research design } \\
\text { SORT } \\
\text { Level } 3\end{array}$ & $\begin{array}{l}\text { Bundle consisted } \\
\text { of daily skin } \\
\text { assessment; regular } \\
\text { repositioning; } \\
\text { nutritional } \\
\text { assessment; calorie } \\
\text { intake; glucose } \\
\text { control; and } \\
\text { redistribution } \\
\text { surfaces. }\end{array}$ & $\begin{array}{l}\text { Not indicated; } \\
\text { however, the } \\
\text { holistic theory of } \\
\text { the whole is more } \\
\text { than the sum of its } \\
\text { components may } \\
\text { be appropriate. }\end{array}$ & $\begin{array}{l}\text { Prevalence rate- } \\
\text { the number of new } \\
\text { and existing } \\
\text { pressure injuries at } \\
\text { a given time } \\
\text { multiplied by total } \\
\text { number of patients } \\
\text { in the same given } \\
\text { time }\end{array}$ & $\begin{array}{l}\text { Reduction of the } \\
\text { prevalence of PIs } \\
\text { from } 12.4 \% \text { to } \\
6.1 \% \text { with bundle } \\
\text { implementation }\end{array}$ \\
\hline $\begin{array}{l}\text { Coyer, F., Gardner, A., } \\
\text { Doubrovsky, A., Cole, R., } \\
\text { Ryan, F. M., Allen, C., \& } \\
\text { McNamara, G. (2015). } \\
\text { Reducing pressure injuries in } \\
\text { critically ill patients by using a } \\
\text { patient skin integrity care } \\
\text { bundle (InSPiRE). American } \\
\text { Journal of Critical Care, } \\
\text { 24(3), 199-209. } \\
\text { doi:10.4037/ajcc2015930 }\end{array}$ & 207 & $\begin{array}{l}\text { Pre and post- test } \\
\text { design } \\
\text { SORT } \\
\text { Level } 2\end{array}$ & $\begin{array}{l}\text { InSPiRE bundle- } \\
\text { interventional skin } \\
\text { integrity bundle to } \\
\text { reduce pressure } \\
\text { injuries in critically } \\
\text { ill patients. }\end{array}$ & $\begin{array}{l}\text { Not indicated, } \\
\text { suspects that the } \\
\text { study applied the } \\
\text { "all or nothing" } \\
\text { approach based on } \\
\text { the holistic theory } \\
\text { of the whole is } \\
\text { more than the total } \\
\text { of its parts }\end{array}$ & $\begin{array}{l}\text { Incidence- is the } \\
\text { number of newly } \\
\text { developed } \\
\text { pressure injuries at } \\
\text { a given time } \\
\text { multiplied by } 100 \\
\text { divided by total } \\
\text { number of patients } \\
\text { in the same given } \\
\text { time }\end{array}$ & $\begin{array}{l}\text { Significantly lower } \\
\text { incidence in the } \\
\text { intervention group } \\
\text { compared to in the } \\
\text { control group for } \\
\text { skin injuries and } \\
\text { mucosal injuries. }\end{array}$ \\
\hline
\end{tabular}




\begin{tabular}{|c|c|c|c|c|c|c|}
\hline $\begin{array}{l}\text { Gill, E. (2015). Reducing hospital- } \\
\text { acquired pressure ulcers in } \\
\text { intensive care. British Medical } \\
\text { Journal, } 4 \text { (1). doi: } \\
\text { 10.1136/bmjquality.u205599.w3015 }\end{array}$ & & $\begin{array}{l}\text { Pre- and post- } \\
\text { intervention design } \\
\text { SORT } \\
\text { Level } 3\end{array}$ & $\begin{array}{l}\text { Staff education on } \\
\text { PI prevention, } \\
\text { Braden risk } \\
\text { assessment; use of } \\
\text { colored signs to } \\
\text { indicate high risk } \\
\text { patients; pressure- } \\
\text { relieving mattress; } \\
\text { turn every } 2 \text { hours; } \\
\text { application of } \\
\text { protective dressing } \\
\text { on areas where } \\
\text { respiratory devices } \\
\text { are used. }\end{array}$ & Not indicated & $\begin{array}{l}\text { Incidence rate - } \\
\text { new cases of PIs } \\
\text { developed while } \\
\text { in the ICU }\end{array}$ & $\begin{array}{l}\text { Incidence rate of } \\
\text { hospital-acquired } \\
\text { pressure ulcers } \\
\text { from } 50 \% \text { to } 0 \% \\
\text { in one year }\end{array}$ \\
\hline $\begin{array}{l}\text { Richardson, A., Peart, J., Wright, } \\
\text { S., \& Mccullagh (2017). Reducing } \\
\text { the incidence of pressure ulcers in } \\
\text { critical care units: a 4-year quality } \\
\text { improvement. International Journal } \\
\text { for Quality in Healthcare, 29(3), } \\
\text { 433-439. doi: } \\
\text { 10.1093/intqhc/mzx040 }\end{array}$ & $\begin{array}{l}\text { Pre-post study } \\
\text { design } \\
\text { SORT } \\
\text { Level } 3\end{array}$ & & $\begin{array}{l}\text { Bundle of } \\
\text { technical and non- } \\
\text { technical } \\
\text { interventions with } \\
\text { components } \\
\text { including changes } \\
\text { to the mattress, } \\
\text { focused risk } \\
\text { assessment, } \\
\text { repositioning } \\
\text { every } 2 \text { hours, and } \\
\text { staff training }\end{array}$ & $\begin{array}{l}\text { Not indicated, } \\
\text { holistic theory } \\
\text { may be applicable } \\
\text { as individual } \\
\text { interventions were } \\
\text { combined and } \\
\text { implemented } \\
\text { collectively }\end{array}$ & $\begin{array}{l}\text { Incidence rare- } \\
\text { new cases of PIs } \\
\text { over } 100 \text { patient } \\
\text { admissions }\end{array}$ & $\begin{array}{l}\text { Significantly } \\
\text { reduced PIs from } \\
8.08 / 100 \text { patient } \\
\text { admissions } \\
\text { (baseline) to } \\
2.97 / 100 \text { patient } \\
\text { admissions or a } \\
63 \% \text { rate } \\
\text { reduction over } \\
\text { four years }\end{array}$ \\
\hline
\end{tabular}




\begin{tabular}{|c|c|c|c|c|c|c|}
\hline $\begin{array}{l}\text { Roberts, S., Mcinnes, E., Wallis, } \\
\text { M., Bucknall, T., Banks, M., \& } \\
\text { Chaboyer, W. (2016). Nurses' } \\
\text { perceptions of a pressure ulcer } \\
\text { prevention care bundle: A } \\
\text { qualitative descriptive study. Bio } \\
\text { Medicine Central Nursing, 15 (64). } \\
\text { doi: } 10.1186 / \text { s12912-016-0188-9 }\end{array}$ & 18 & $\begin{array}{l}\text { Qualitative } \\
\text { descriptive } \\
\text { research design } \\
\text { SORT } \\
\text { Level } 3\end{array}$ & PUPCB & $\begin{array}{l}\text { Not stated, } \\
\text { although it appears } \\
\text { that the authors } \\
\text { drew from Roger's } \\
\text { diffusion of } \\
\text { innovation, } \\
\text { PARIHS, and } \\
\text { Greenhalgh's } \\
\text { Innovation-system } \\
\text { fit theory }\end{array}$ & & $\begin{array}{l}\text { Nurses reported } \\
\text { bundle easily } \\
\text { understood as their } \\
\text { awareness } \\
\text { increased thru } \\
\text { communication, } \\
\text { and participation in } \\
\text { PUP care. Bundle } \\
\text { implementation } \\
\text { requires leadership, } \\
\text { communication and } \\
\text { partnership with } \\
\text { staff. }\end{array}$ \\
\hline $\begin{array}{l}\text { Tayyib \& Coyer (2017). } \\
\text { Translating pressure ulcer } \\
\text { prevention into intensive care } \\
\text { nursing practice. Journal of } \\
\text { Nursing Quality, 32(1), 6-14. doi: } \\
\text { 10.1097/NCQ.0000000000000199 }\end{array}$ & & $\begin{array}{l}2 \text { arm -cluster } \\
\text { randomized } \\
\text { control trial } \\
\text { SORT } \\
\text { Level } 3\end{array}$ & PUP bundle & $\begin{array}{l}\text { Ottawa Model of } \\
\text { Research Use } \\
\text { (OMRU) }\end{array}$ & $\begin{array}{l}\text { Incidence rate- is } \\
\text { the proportion of } \\
\text { participants who } \\
\text { developed a new } \\
\text { PI within a } \\
\text { specific time } \\
\text { divided by the } \\
\text { total number of } \\
\text { participants who } \\
\text { were at risk for } \\
\text { PIs. }\end{array}$ & $\begin{array}{l}\text { Significantly fewer } \\
\text { PIs from } 32.86 \% \text { to } \\
7.14 \% \text {. } \\
\text { Intervention group } \\
\text { has significantly } \\
\text { reduced stage } 1,2 \text {, } \\
\text { and less medical } \\
\text { device-related PIs. }\end{array}$ \\
\hline
\end{tabular}




\begin{tabular}{|c|c|c|c|c|c|c|}
\hline $\begin{array}{l}\text { Tayyib, N., Coyer, F., \& Lewis, P. } \\
\text { A. (2016). Implementing a } \\
\text { pressure ulcer prevention bundle } \\
\text { in an adult intensive } \\
\text { care. Intensive and Critical Care } \\
\text { Nursing, 37, 27-36. }\end{array}$ & $11 \mathrm{RNs}$ & $\begin{array}{l}\text { Observational } \\
\text { prospective study } \\
\text { design } \\
\text { SORT } \\
\text { Level } 3\end{array}$ & $\begin{array}{l}\text { Pressure ulcer } \\
\text { preventive bundle }\end{array}$ & $\begin{array}{l}\text { Not stated; } \\
\text { however, Roger } \\
\text { Innovation } \\
\text { diffusion theory } \\
\text { may have been } \\
\text { adapted by the } \\
\text { authors }\end{array}$ & $\begin{array}{l}\text { Incidence rate- } \\
\text { the number of } \\
\text { newly } \\
\text { developed } \\
\text { pressure ulcer at } \\
\text { a given time }\end{array}$ & $\begin{array}{l}\text { Reduced incidence } \\
\text { of PIs.. Strategies } \\
\text { are essential in } \\
\text { measuring staff } \\
\text { compliance and } \\
\text { interpreting } \\
\text { findings. } \\
\text { Familiarity of the } \\
\text { staff with the } \\
\text { bundle was related } \\
\text { to increased } \\
\text { compliance }\end{array}$ \\
\hline $\begin{array}{l}\text { Tayyib, N., Coyer, F., \& Lewis, P. } \\
\text { A. (2015). A two-arm cluster } \\
\text { randomized control trial to } \\
\text { determine the effectiveness of a } \\
\text { pressure ulcer prevention bundle } \\
\text { for critically ill patients. Journal } \\
\text { of Nursing Scholarship, } 47(3) \text {, } \\
\text { 237-247. doi:10.1111/jnu.12136 }\end{array}$ & 140 & $\begin{array}{l}\text { A two-arm cluster, } \\
\text { randomized, } \\
\text { experimental } \\
\text { research } \\
\text { design } \\
\text { SORT } \\
\text { Level } 2\end{array}$ & $\begin{array}{l}\text { Pressure injury } \\
\text { prevention bundle }\end{array}$ & $\begin{array}{l}\text { Not indicated in } \\
\text { the article; } \\
\text { however, the } \\
\text { assumption is the } \\
\text { authors adapted the } \\
\text { holistic theory of } \\
\text { the whole is more } \\
\text { than the sum of its } \\
\text { parts }\end{array}$ & $\begin{array}{l}\text { Incidence- is the } \\
\text { number of new } \\
\text { pressure injuries } \\
\text { in adult ICU } \\
\text { patients at a } \\
\text { given time }\end{array}$ & $\begin{array}{l}\text { PU cumulative } \\
\text { incidence was } \\
\text { significantly lower } \\
\text { in the intervention } \\
\text { group }(7.14 \%) \\
\text { compared to the } \\
\text { control group } \\
\text { (32.86. The } \\
\text { intervention group } \\
\text { had significantly } \\
\text { less Stage I (p = } \\
.002) \text { and Stage II } \\
\text { PU development }\end{array}$ \\
\hline
\end{tabular}

Legend: ICU- Intensive Care Unit; Ottawa Model of Research Use (OMRU); PUP- Pressure Ulcer Prevention; PUPCB- Pressure Ulcer Prevention Care Bundle; RNs- Registered Nurses; UPUPB-Universal Pressure Ulcer Prevention Bundle; WOC- Wound Ostomy Continence. 


\section{Appendix B}

Summary of Systematic Reviews (SR)

\begin{tabular}{|c|c|c|c|c|c|c|c|}
\hline Citation & Question & Search Strategy & $\begin{array}{l}\text { Inclusion/Exclusion } \\
\text { Criteria }\end{array}$ & $\begin{array}{c}\text { Data Extraction } \\
\text { \& Analysis }\end{array}$ & Key Findings & Recommendations & $\begin{array}{l}\text { Level of } \\
\text { Evidence }\end{array}$ \\
\hline $\begin{array}{l}\text { Tayyib, N., \& } \\
\text { Coyer, F. (2016). } \\
\text { Effectiveness of } \\
\text { pressure ulcer } \\
\text { prevention strategies } \\
\text { for adult patients in } \\
\text { intensive care } \\
\text { units. Joanna Briggs } \\
\text { Institute Database } \\
\text { of Systematic } \\
\text { Reviews and } \\
\text { Implementation } \\
\text { Reports, 14(3), 35- } \\
\text { 44. } \\
\text { doi:10.11124/jbisrir- } \\
\text { 2016-2400 }\end{array}$ & $\begin{array}{l}\text { Effectiveness } \\
\text { of single } \\
\text { intervention to } \\
\text { reduce the } \\
\text { incidence andA } \\
\text { prevalence of } \\
\text { HAPU in ICU } \\
\text { in comparison } \\
\text { to different PU } \\
\text { prevention } \\
\text { strategies, } \\
\text { standard or } \\
\text { usual practice. }\end{array}$ & $\begin{array}{l}\text { Database } \\
\text { utilized include } \\
\text { CINAHL, } \\
\text { Medline } \\
\text { (PubMed) } \\
\text { journals, } \\
\text { Cochrane } \\
\text { Central } \\
\text { Register of } \\
\text { Controlled } \\
\text { Trials, Web of } \\
\text { Science, } \\
\text { Embase, ERIC, } \\
\text { Scopus, and } \\
\text { Mednar (2000 - } \\
\text { 2015). The } \\
\text { unpublished } \\
\text { studies } \\
\text { consisted of } \\
\text { New York } \\
\text { Academy of } \\
\text { Medicine }\end{array}$ & $\begin{array}{l}\text { Quantitative } \\
\text { experimental studies, } \\
\text { randomized } \\
\text { controlled trials } \\
\text { (RCT), non- } \\
\text { randomized } \\
\text { controlled trials, } \\
\text { quasi experimental, } \\
\text { pre and post, and } \\
\text { comparative studies } \\
\text { published in English } \\
\text { from 2000-2015 with } \\
\text { adult participants, } 18 \\
\text { years and above } \\
\text { admitted in the ICU, } \\
\text { incidence and } \\
\text { prevalence as } \\
\text { primary outcome } \\
\text { measures }\end{array}$ & $\begin{array}{l}\text { Two } \\
\text { independent } \\
\text { reviewers } \\
\text { utilized the JBI- } \\
\text { MAStARI } \\
\text { appraisal tool in } \\
\text { reviewing } \\
\text { studies for } \\
\text { inclusion. } \\
\text { Studies that met } \\
\text { 50\% of inclusion } \\
\text { were considered } \\
\text { and presented in } \\
\text { a narrative form. } \\
\text { A third reviewer } \\
\text { resolved any } \\
\text { disagreements. }\end{array}$ & $\begin{array}{l}\text { Application of } \\
\text { prophylactic } \\
\text { silicone foam } \\
\text { dressing over the } \\
\text { sacrum is } \\
\text { effective in } \\
\text { reducing } \\
\text { incidence of PIs. } \\
\text { Two studies } \\
\text { reported a } \\
\text { significantly } \\
\text { decreased HAPU } \\
\text { incidence with } \\
\text { application of } \\
\text { silicone dressing } \\
\text { prophylactically } \\
\text { on the heels. } \\
\text { Nutrition- one } \\
\text { study with } \\
\text { significant } \\
\text { reduction of } \\
\text { HAPUs with } \\
\text { acute lung } \\
\text { injuries with } \\
\text { specific dietary } \\
\text { interventions. } \\
\text { Prone positioning } \\
\text { the patient in bed } \\
\text { combined with } \\
\text { application of } \\
\text { silicone dressing } \\
\text { was reported to } \\
\text { be associated }\end{array}$ & $\begin{array}{l}\text { Development of } \\
\text { Risk Assessment of } \\
\text { Skin and Tissues } \\
\text { (RAST) to identify } \\
\text { patients at risks for } \\
\text { PUs and initiate PI } \\
\text { prevention } \\
\text { strategies. } \\
\text { Conduct additional } \\
\text { studies in managing } \\
\text { skin moisture and } \\
\text { promote skin } \\
\text { hygiene especially } \\
\text { in sacral areas. } \\
\text { Evaluate use of } \\
\text { support surface } \\
\text { products. } \\
\text { Utilization of } \\
\text { prophylactic silicone } \\
\text { foam dressing over } \\
\text { the sacrum and } \\
\text { heels. } \\
\text { Frequent } \\
\text { repositioning, 2- } \\
\text { hour repositioning, } \\
\text { is considered to be a } \\
\text { standard of care to } \\
\text { prevent PU } \\
\text { development } \\
\text { Include monitoring } \\
\text { the degree of } \\
\text { compliance to either } \\
\text { the strategy itself or }\end{array}$ & $\begin{array}{l}\text { SORT } \\
\text { Level } 1\end{array}$ \\
\hline
\end{tabular}




\begin{tabular}{|l|l|l|l|l|}
\hline & & & & $\begin{array}{l}\text { with significantly } \\
\text { greater HAPU } \\
\text { development } \\
\text { compared to a } \\
\text { supine position in } \\
\text { the first seven } \\
\text { days of patient } \\
\text { admission. } \\
\text { Support surfaces- } \\
\text { alternating } \\
\text { pressure mattress } \\
\text { significantly } \\
\text { lowered the } \\
\text { incidence of } \\
\text { HAPUs, stage II } \\
\text { or greater } \\
\text { compared to } \\
\text { using foam } \\
\text { overlay mattress. } \\
\text { Significant } \\
\text { improvement in } \\
\text { the incidence of } \\
\text { medical related } \\
\text { device for non- } \\
\text { invasive } \\
\text { ventilation was } \\
\text { reported with the } \\
\text { use of prototype } \\
\text { face masks }\end{array}$ \\
& \\
&
\end{tabular}




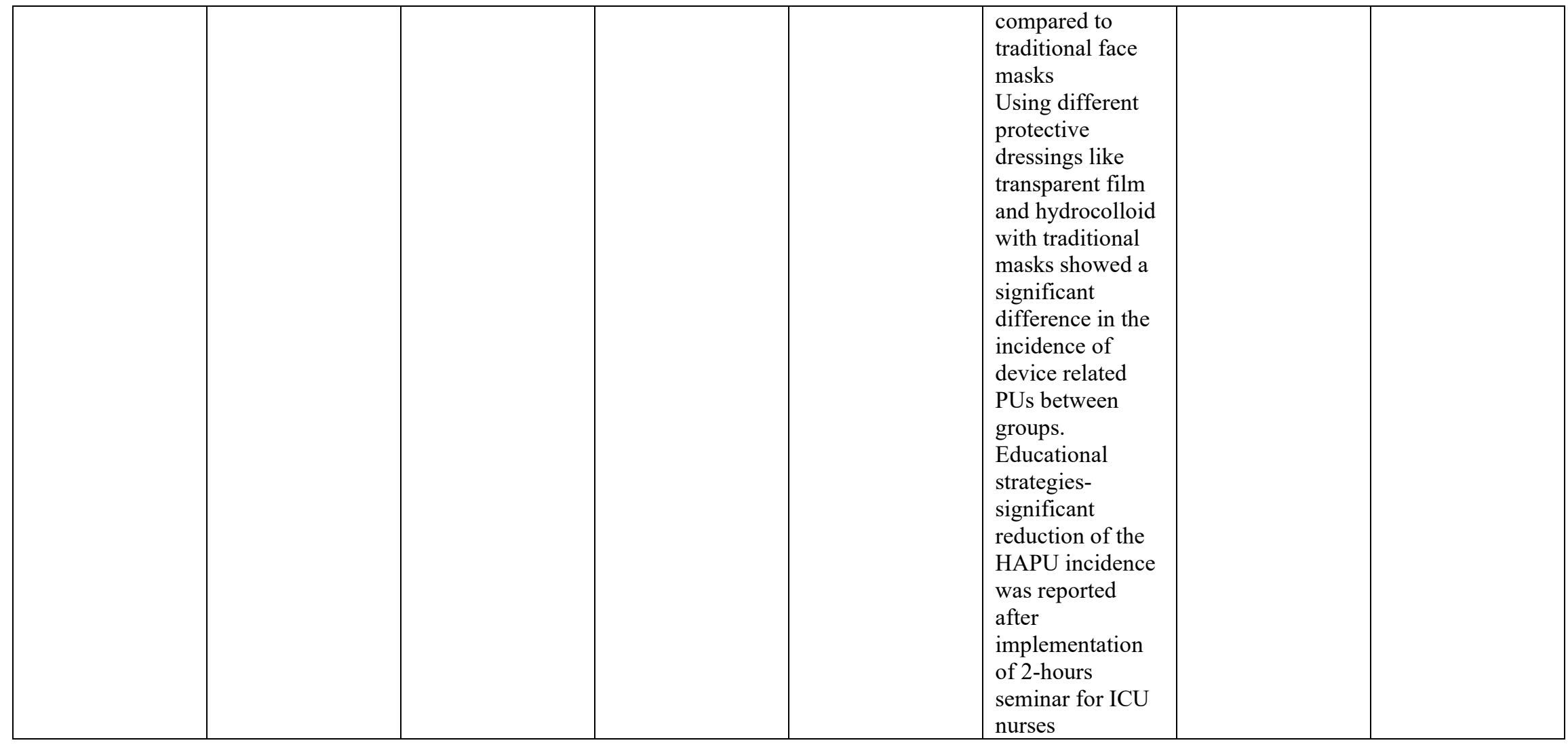




\section{Appendix C}

\section{Synthesis Matrix}

\begin{tabular}{|c|c|c|c|c|}
\hline Main Idea & Reference \# 1 & Reference \#2 & Reference \#3 & Reference \#4 \\
\hline & $\begin{array}{l}\text { Amr, A., Yousef, A., } \\
\text { Amirah, M., \& Alkurdi, M. } \\
\text { (2017). A pre-post study } \\
\text { evaluating the effectiveness } \\
\text { of a new initiative, the } \\
\text { "PRESSURE Bundle," } \\
\text { compared with standard care } \\
\text { in reducing the incidence } \\
\text { and prevalence of sacral } \\
\text { pressure ulcers in critically } \\
\text { ill patients in an intensive } \\
\text { care unit in Riyadh, Saudi } \\
\text { Arabia. Saudi Critical Care } \\
\text { Journal, 1(3), 75. } \\
\text { doi:10.4103/sccj.sccj_29_7 }\end{array}$ & $\begin{array}{l}\text { Anderson, M.,Guthrie, O., Kraft, } \\
\text { W., Reicks, P., Skay, C., \& Beal, } \\
\text { A. (2015). Universal pressure } \\
\text { ulcer prevention bundle with } \\
\text { Wound Ostomy Continence nurse } \\
\text { support. Journal of } \\
\text { Wound,Ostomy and Continence } \\
\text { Nurses Society, 42(3), 217-225. } \\
\text { doi: } \\
\text { 10.1097/WON.000000000000.109 }\end{array}$ & $\begin{array}{l}\text { Carino, G.,Ricci, D., Bartula, D., } \\
\text { Manzo, E., \& Sargent, J. (2012). } \\
\text { The HAPU bundle: A tool to } \\
\text { reduce the incidence of hospital- } \\
\text { acquired pressure ulcers in the } \\
\text { ICU. International Journal of } \\
\text { Nursing Sciences, } 2 \\
\text { (4), 34-37. } \\
\text { doi:10.5923/j.nursing.20120204.02 }\end{array}$ & $\begin{array}{l}\text { Coyer, F., et al. (2015). Reducing } \\
\text { pressure injuries in critically ill } \\
\text { patients by using a patient skin } \\
\text { integrity care bundle (InSPire). } \\
\text { American Journal of Critical Care, } 24 \\
\text { (3), 199-209. doi: } \\
\text { http://dx.doi.org/10.4037/ajcc2015930 }\end{array}$ \\
\hline Setting & Riyadh, Saudi Arabia & Minnesota & Providence, RI & Australia \\
\hline $\begin{array}{l}\text { Reasons for } \\
\text { High Risks } \\
\text { in ICU } \\
\text { Patients }\end{array}$ & $\begin{array}{l}\text { Immobility, severity of } \\
\text { illness, use of ventilator, } \\
\text { sedation, pharmacological } \\
\text { drugs, and impaired } \\
\text { nutrition. }\end{array}$ & $\begin{array}{l}\text { Immobility, hemodynamic } \\
\text { instability. }\end{array}$ & & $\begin{array}{l}\text { Critical illness and admission to ICU } \\
\text { increased risks for PI development. } \\
\text { Immobility, use of medical devices, } \\
\text { intravenous sedation, vasopressor use }\end{array}$ \\
\hline
\end{tabular}




\begin{tabular}{|c|c|c|c|c|}
\hline Incidence of PIs & $\begin{array}{c}\text { Control group- }(\mathrm{n}=16,4.6 \%) \\
\text { Intervention group }(\mathrm{n}=1, \\
0.3 \%)\end{array}$ & $15.5 \%$ to $2.1 \%$ over 6 months & $\begin{array}{l}\text { Prevalence: } \\
12.4 \%(21 / 169) \text { to } 6.1 \% \\
(11 / 167) \text { in } 12 \text { months }\end{array}$ & $\begin{array}{l}18.1 \% \text { in intervention group } \\
30.4 \% \text { in the control group }\end{array}$ \\
\hline $\begin{array}{l}\text { Rationale for Bundle } \\
\text { Implementation }\end{array}$ & & $\begin{array}{l}\text { Bundle is clear and concise. } \\
\text { Effective in reducing VAPs, } \\
\text { CLABSIs, and is evidenced- } \\
\text { based }\end{array}$ & $\begin{array}{l}\text { Bundle is simple, specific, } \\
\text { and evidence-based process. } \\
\text { Been effective to attain } \\
\text { measurable improvements in } \\
\text { multiple conditions (VAP, } \\
\text { CLABSIs, Sepsis }\end{array}$ & \\
\hline Bundle Components & $\begin{array}{l}\text { PRESSURE } \\
\text { Positioning, } \\
\text { Risk assessment (Braden) } \\
\text { Elevation of heels } \\
\text { Skin assessment } \\
\text { Skincare and protective } \\
\text { barrier (Mepilex) } \\
\text { Ultimate nutrition, } \\
\text { Relief of pressure (air } \\
\text { mattress and turning every } 2 \\
\text { hours), and } \\
\text { Elevation of head of bed }<30^{\circ}\end{array}$ & $\begin{array}{l}\text { From critical appraisal of } \\
\text { current appraisal. } \\
\text { SAFER bundle: } \\
\text { S-kin emollients } \\
\text { Assessment head to toe } \\
\text { Floating heels off the bed } \\
\text { Early identification of sources } \\
\text { of pressure using pressure } \\
\text { redistribution surfaces, and } \\
\text { Repositioning }\end{array}$ & $\begin{array}{l}6 \text { individual measures: daily } \\
\text { skin assessment by a } \\
\text { physician, turning every } 2 \\
\text { hours, nutritional assessment, } \\
\text { calorie intake, glucose } \\
\text { controls \& redistribution } \\
\text { surfaces }\end{array}$ & $\begin{array}{l}\text { InSpiRe protocol: } \\
\text { Skin assessment; skin } \\
\text { hygiene; turning every } 3 \\
\text { hours minimum using a turn } \\
\text { team; elimination of pressure } \\
\text { and friction related mucosal } \\
\text { injury development; } \\
\text { elimination of heel pressure; } \\
\text { optimize nutrition; and } \\
\text { promotion of mobility }\end{array}$ \\
\hline $\begin{array}{l}\text { Use of Multidisciplinary } \\
\text { Approach }\end{array}$ & $\begin{array}{l}\text { ICU woundcare team: } \\
\text { intensivist, quality manager, } \\
\text { clinical dietician, nursing } \\
\text { educator, and nursing } \\
\text { supervisor nursing educator, } \\
\text { and nursing supervisor. }\end{array}$ & & & Champions were utilized \\
\hline Evaluation of Compliance & $\begin{array}{l}\text { Compliance monitored daily. } \\
\text { Monthly updates of incidence } \\
\text { and prevalence to ensure } \\
\text { compliance. } \\
90 \% \text { compliance achieved to } \\
\text { components }\end{array}$ & $\begin{array}{l}\text { Educational strategies and } \\
\text { ongoing coaching. } \\
\text { Semi-weekly rounds by the } \\
\text { WOC nurse. Calculation of } \\
\text { adherence rate. }\end{array}$ & $\begin{array}{l}\text { Compliance checklist on skin } \\
\text { assessment; turning; } \\
\text { nutrition; surface support. }\end{array}$ & $\begin{array}{l}\text { Measured compliance by } \\
\text { ongoing education, cyclical } \\
\text { feedback, and using } \\
\text { adherence checklist. } \\
\text { Educational training to staff, } \\
\text { brochures, in-service, group } \\
\text { presentation. }\end{array}$ \\
\hline
\end{tabular}




\begin{tabular}{|c|c|c|c|c|}
\hline & Reference \#5 & Reference \#6 & Reference\#7 & Reference \#8 \\
\hline Main Idea & $\begin{array}{l}\text { Gill, E. (2015). Reducing hospital- } \\
\text { acquired pressure ulcers in intensive } \\
\text { care. British Medical Journal, 4(1), } \\
\text { 2055-3015. } \\
\text { doi:10.1136/bmiquality.u205599.w3015 }\end{array}$ & $\begin{array}{l}\text { Richardson, A., Peart, J., } \\
\text { Wright, S., \& Mccullagh } \\
\text { (2017). Reducing the } \\
\text { incidence of pressure } \\
\text { ulcers in critical care units: } \\
\text { a 4-year quality } \\
\text { improvement. International } \\
\text { Journal for Quality in } \\
\text { Healthcare, 29(3), 433- } \\
\text { 439. doi: } \\
\text { 10.1093/intqhc/mzx040 }\end{array}$ & $\begin{array}{l}\text { Roberts, S., Mcinnes, E., } \\
\text { Wallis, M., Bucknall, T., } \\
\text { Banks, M., \& Chaboyer, } \\
\text { W. (2016). Nurses' } \\
\text { perceptions of a pressure } \\
\text { ulcer prevention care } \\
\text { bundle: A qualitative } \\
\text { descriptive study. Bio } \\
\text { Medicine Central } \\
\text { Nursing, } 15 \text { (64). doi: } \\
\text { 10.1186/s12912-016- } \\
0188-9\end{array}$ & $\begin{array}{l}\text { Tayyib \& Coyer (2017). } \\
\text { Translating pressure ulcer } \\
\text { prevention into intensive care } \\
\text { nursing practice. Journal of } \\
\text { Nursing Quality, 32(1), 6-14. doi: } \\
\text { 10.1097/NCQ.0000000000000199 }\end{array}$ \\
\hline Setting & United Arab Emirates & Tyne, UK & Australia & Saudi Arabia \\
\hline $\begin{array}{l}\text { Reasons for High } \\
\text { Risks in ICU Patients }\end{array}$ & $\begin{array}{l}\text { Patients intubated, ventilated, on } \\
\text { inotropes, complete bed rest or } \\
\text { restricted mobility, and suffered from } \\
\text { diarrhea. }\end{array}$ & $\begin{array}{l}\text { Incontinence, immobility, } \\
\text { impaired nutrition, } \\
\text { inotropes, mechanical } \\
\text { ventilation. }\end{array}$ & & $\begin{array}{l}\text { High acuity, physiological } \\
\text { responses to critical illness, and } \\
\text { length of stay in the ICU. ICU is a } \\
\text { dynamic and complex } \\
\text { environment. }\end{array}$ \\
\hline Incidence of PIs & $50 \%$ to $0 \%$ in 1 year & & $\begin{array}{l}8.08 \% / 100 \text { patient } \\
\text { admissions to } 2.97 / 100 \\
\text { patient admissions or } \\
63 \% \text { relative rate } \\
\text { reduction in } 4 \text { years }\end{array}$ & $\begin{array}{l}32.86 \%(23 / 70 \text { patients }) \text { to } 7.14 \% \\
(5 / 70 \text { patients }\end{array}$ \\
\hline $\begin{array}{l}\text { Rationale for Bundle } \\
\text { Implementation }\end{array}$ & Non-adherence to prevention guidelines & $\begin{array}{l}\text { Recent introduction of } \\
\text { using bundle with the } \\
\text { PDSA approach with } \\
\text { improvement in CLABSI }\end{array}$ & & $\begin{array}{l}\text { More effective than simply } \\
\text { following clinical guidelines. } \\
\text { Bundle is reliable, easy, \& clear to } \\
\text { implement, and contextual. }\end{array}$ \\
\hline
\end{tabular}




\begin{tabular}{|c|c|c|c|c|}
\hline Bundle Components & $\begin{array}{l}\text { Staff education on pressure } \\
\text { ulcer prevention, timely and } \\
\text { accurate risk assessment } \\
\text { (Braden Risk } 6 \text { hours upon } \\
\text { admission), frequent } \\
\text { repositioning and offloading, } \\
\text { and moisture management. }\end{array}$ & $\begin{array}{l}\text { Evidence, appraisal, changes } \\
\text { to mattress, focused-risk } \\
\text { assessment, turning every } 2 \\
\text { hours, staff training on } \\
\text { prevention with the support } \\
\text { of clinical leadership. }\end{array}$ & $\begin{array}{l}\text { PUPCB } \\
\text { Keep moving, look after your } \\
\text { skin, and eat healthy diet. }\end{array}$ & $\begin{array}{l}\text { Bundle components } \\
\text { contextualized: use of air } \\
\text { mattress because of its } \\
\text { availability; turning every } 3 \\
\text { hours. }\end{array}$ \\
\hline $\begin{array}{c}\text { Use of Multidisciplinary } \\
\text { Approach }\end{array}$ & $\begin{array}{l}\text { Tissue viability team, nursing } \\
\text { management, PUP team, } \\
\text { respire-tory therapist within } \\
\text { the ICU }\end{array}$ & $\begin{array}{l}\text { Pressure ulcer task group } \\
\text { with a nurse consultant, } \\
\text { charge nurse, staff nurses, } \\
\text { consultant in critical care, } \\
\text { critical data monitoring } \\
\text { specialist, and a tissue } \\
\text { viability nurse specialist. }\end{array}$ & $\begin{array}{l}\text { Use of trained research } \\
\text { assistants to conduct } \\
\text { interviews. }\end{array}$ & $\begin{array}{l}\text { Utilized collaboration } \\
\text { approach with nursing, } \\
\text { medicine, pharmacy, and } \\
\text { dietician. }\end{array}$ \\
\hline Evaluation of Compliance & $\begin{array}{l}\text { Developed a traffic light } \\
\text { system of red, yellow, green } \\
\text { to identify the patients at risk. } \\
\text { Red for score of } 9 \text {; yellow for } \\
\text { medium risk or score of } 12 \text { or } \\
\text { less; green for score of } \\
\text { greater than } 12 \text {. Compliance } \\
\text { monitored daily. Audit } \\
\text { weekly. } 100 \% \text { compliance } \\
\text { with Braden; } 80 \% \text { on color- } \\
\text { coded signs; } 50 \% \text { on turning; } \\
\text { turning clocks and leading by } \\
\text { examples. }\end{array}$ & $\begin{array}{l}\text { Auditing, providing timely } \\
\text { feedback, and monitoring. } \\
\text { Turning is the most } \\
\text { challenging because of the } \\
\text { instability of the patients. } \\
\text { Staff training. }\end{array}$ & $\begin{array}{l}\text { Identified } 5 \text { Themes on } \\
\text { nurses' perceptions of the } \\
\text { bundle: awareness of the } \\
\text { PUPCB, improving } \\
\text { awareness through } \\
\text { communication and } \\
\text { participation, appreciating the } \\
\text { positive aspects of patient } \\
\text { participation, perceived } \\
\text { barriers to engaging patients } \\
\text { and partnering with the } \\
\text { nursing staff in the } \\
\text { implementation. }\end{array}$ & $\begin{array}{l}\text { Use of interactive educational } \\
\text { in-service regarding the } \\
\text { bundle. Bi-weekly reminders } \\
\text { of the study, reminders during } \\
\text { the monthly ICU meetings } \\
\text { promoted practice change. } \\
\text { Ongoing motivation of staff } \\
\text { through repeating aim of } \\
\text { bundle implementation. Audit } \\
\text { and feedback proven effective } \\
\text { in improving performance. } \\
\text { Audits and personal self- } \\
\text { reports conducted to address } \\
\text { perceived barriers and } \\
\text { facilitators. Requires ongoing } \\
\text { organizational support. }\end{array}$ \\
\hline
\end{tabular}




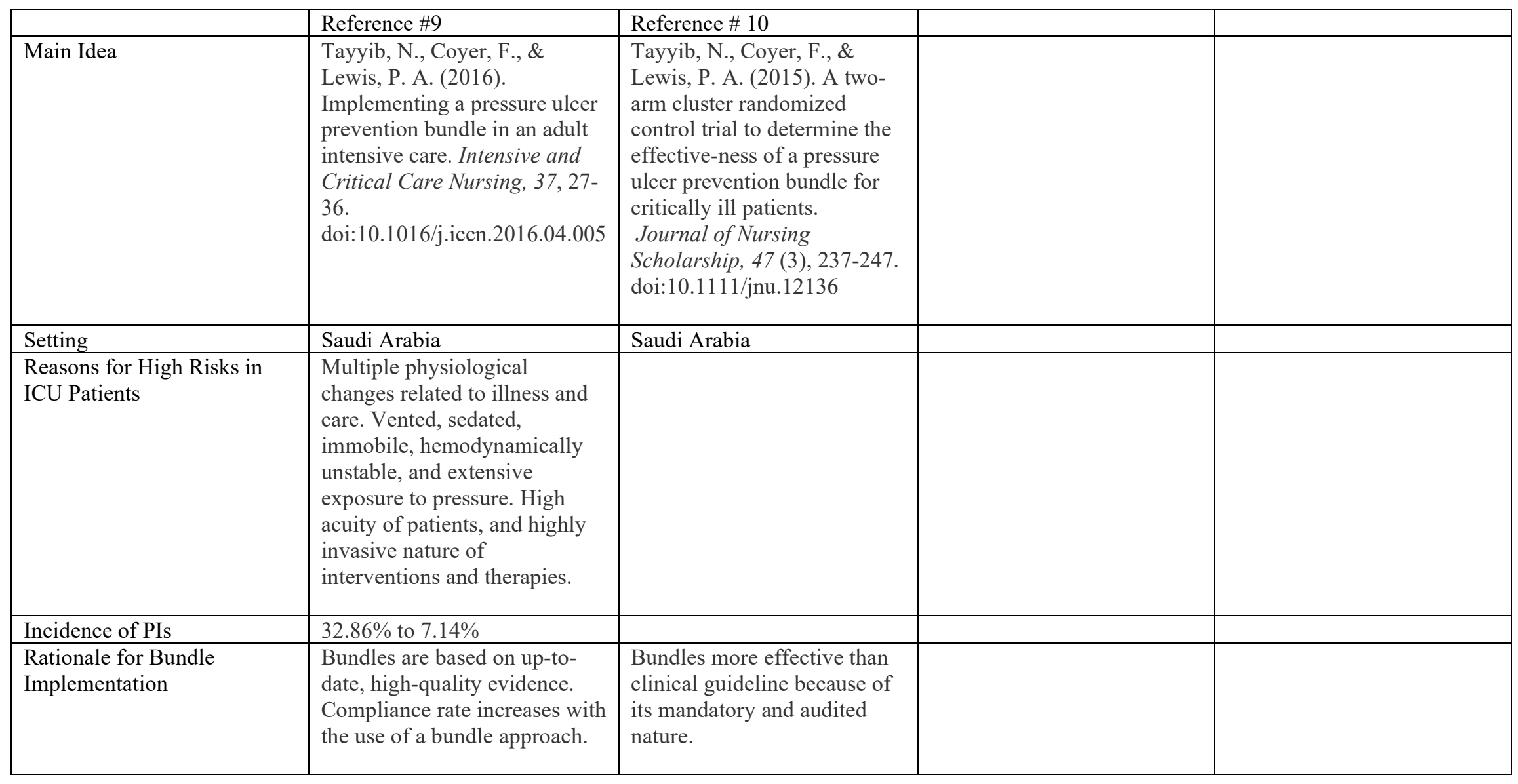




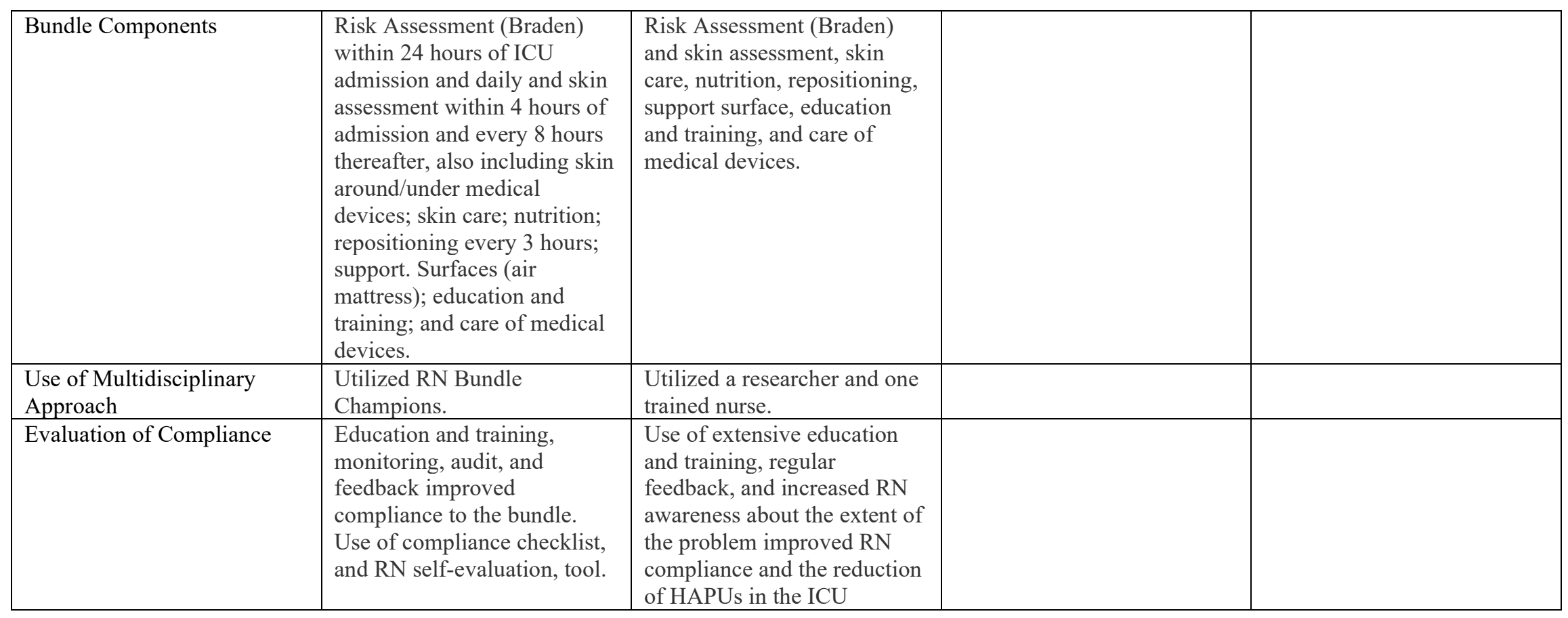


Appendix D

\section{PRISMA Diagram}

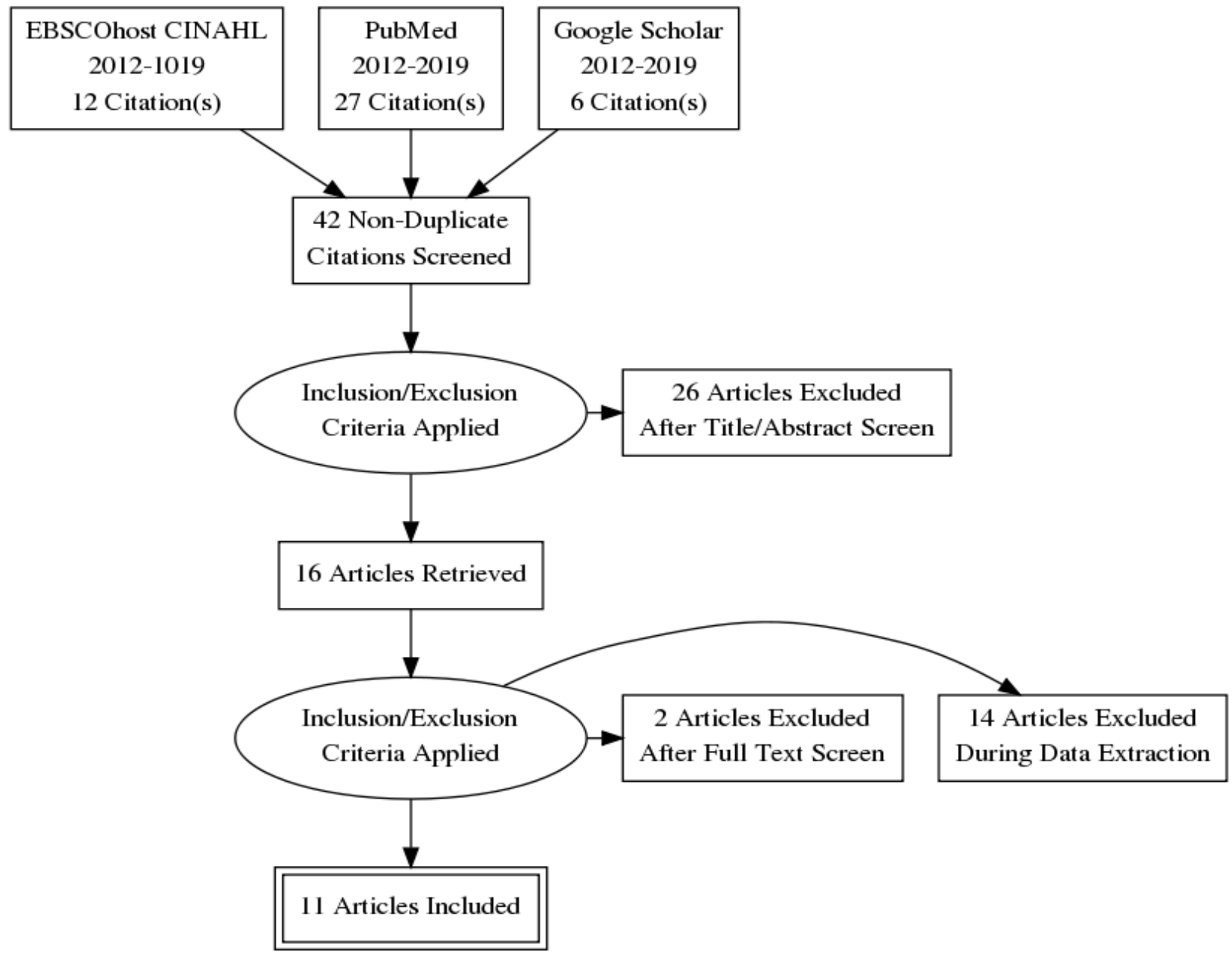


Appendix E

SWOT Analysis

\begin{tabular}{|c|c|}
\hline $\begin{array}{l}\text { Strengths } \\
\text { - Nursing leadership support } \\
\text { - Frontline staff }\end{array}$ & $\begin{array}{l}\text { Opportunities } \\
\text { - } \quad \text { Education and training } \\
\text { - Increase staff awareness } \\
\text { - } \text { ICU Bundle Champions } \\
\text { - } \text { Wound care nurses } \\
\text { - Incorporate into EHR workflow } \\
\quad \text { Incorporate bundle implementation in the policy and procedure } \\
\end{array}$ \\
\hline $\begin{array}{l}\text { Weaknesses } \\
\text { - Not a priority } \\
\text { - Lack of supplies } \\
\text { - ICU nurse turnover } \\
\text { - Lack of accountability } \\
\text { - Inconsistencies }\end{array}$ & $\begin{array}{l}\text { Threats } \\
\text { - Legal implications } \\
\text { - Lack of reimbursements } \\
\text { - Increased costs } \\
\text { - Nurses not accountable } \\
\text { Hospital reputation at stake }\end{array}$ \\
\hline
\end{tabular}




\section{Appendix F}

Objectives of PowerPoint Presentation for Staff Training

\begin{tabular}{|c|c|}
\hline \multicolumn{2}{|l|}{ Objectives } \\
\hline - & Define Pressure Injuries (PIs). \\
\hline - & Describe the difference between a pressure and a shear. \\
\hline - & Present the significance of PIs globally and locally. \\
\hline - & Differentiate incidence vs. prevalence. \\
\hline - & Describe the quality improvement process. \\
\hline - & Explain project scope and project timeline. \\
\hline - & Describe roles and expectations for ICU staff. \\
- & Discuss auditing, monitoring, and providing feedback. \\
\hline
\end{tabular}


Appendix G

Project Timeline

\begin{tabular}{|l|l|l|}
\hline \multicolumn{1}{|c|}{ Steps } & \multicolumn{1}{|c|}{ Time Frame } & \multicolumn{1}{|c|}{ Who Is Responsible } \\
\hline 1. IRB Approval from the University \& Facility & $1 / 10 / 20-2 / 12 / 20$ & DNP student \\
\hline 2. Meet with key stakeholders & $3 / 15 / 20$ & DNP student, CNO, ICU Director \\
\hline 3. Structure and Conduct Staff Training & $3 / 26 / 20-04 / 01 / 20$ & DNP student and Education Director \\
\hline $\begin{array}{l}\text { 4. Start Pressure Injury Preventive Bundle } \\
\text { Implementation }\end{array}$ & $04 / 01 / 20-05 / 31 / 20$ & DNP student \& ICU Bundle Champions \\
\hline 5. Data Analysis & $06 / 01 / 20-06 / 15 / 20$ & DNP student \& Statistician \\
\hline 6. Dissemination of Results & $07 / 01 / 20-09 / 30 / 20$ & \\
\hline & & \\
\hline
\end{tabular}


Appendix $\mathrm{H}$

Budget

\begin{tabular}{|l|l|l|l|}
\hline EXPENSES & & REVENUE & \\
\hline Direct & & Billing & \\
\hline Staff Training & $\$ 6,000.00$ & Grants & \\
\hline Supplies for PI prevention & $\$ 1,000.00$ & & \\
\hline & & & \\
\hline Statistician & & & \\
\hline Posters & & & \\
\hline Rewards for staff for compliance & $\$ 300.00$ & & \\
\hline Indirect & & & \\
\hline Overhead (electricity, etc) & & & \\
\hline Total Expenses & $\$ 7,300.00$ & Total Revenue & \\
\hline Net Balance & & & \\
\hline
\end{tabular}




\section{Appendix I}

\section{Data Collection Tool}

Part 1: Demographic Data:

Participant's ID \#

Age:

BMI:

Gender:

Incidence of PI: Yes/ No

Date of Admission:

Stage and Location of PIs:

Diagnosis:

Length of stay (in days) in the ICU:

Part 2: Compliance Checklist

\begin{tabular}{|c|c|c|c|c|c|c|}
\hline Participants & $\begin{array}{l}\text { Documented Braden } \\
\text { Risk Score (twice daily) }\end{array}$ & $\begin{array}{l}\text { Documented patient } \\
\text { turning every } 2 \\
\text { hours }\end{array}$ & $\begin{array}{l}\text { Documented } \\
\text { nutritional } \\
\text { consult }\end{array}$ & $\begin{array}{l}\text { Documented protective dressing } \\
\text { application (twice daily) indicating } \\
\text { location }\end{array}$ & $\begin{array}{l}\text { Documented } \\
\text { use of air } \\
\text { mattress over } \\
\text { regular } \\
\text { mattress (twice } \\
\text { daily) }\end{array}$ & $\begin{array}{l}\text { Documented } \\
\text { attendance to } \\
\text { training }\end{array}$ \\
\hline 1. & $\begin{array}{l}\text { Yes } \\
\text { No } \\
\text { Staff RN }\end{array}$ & $\begin{array}{l}\text { Yes } \\
\text { No } \\
\text { Staff RN }\end{array}$ & $\begin{array}{l}\text { Yes } \\
\text { No } \\
\text { Staff RN }\end{array}$ & $\begin{array}{l}\text { Yes } \\
\text { No } \\
\text { Where? }\end{array}$ & $\begin{array}{l}\text { Yes } \\
\text { No } \\
\text { Staff RN }\end{array}$ & $\begin{array}{l}\text { Yes } \\
\text { No } \\
\text { Staff RN }\end{array}$ \\
\hline 2. & $\begin{array}{l}\text { Yes } \\
\text { No } \\
\text { Staff RN } \\
\end{array}$ & $\begin{array}{l}\text { Yes } \\
\text { No } \\
\text { Staff RN } \\
\end{array}$ & $\begin{array}{l}\text { Yes } \\
\text { No } \\
\text { Staff RN } \\
\end{array}$ & $\begin{array}{l}\text { Yes } \\
\text { No } \\
\text { Where? }\end{array}$ & $\begin{array}{l}\text { Yes } \\
\text { No } \\
\text { Staff RN } \\
\end{array}$ & $\begin{array}{l}\text { Yes } \\
\text { No } \\
\text { Staff RN } \\
\end{array}$ \\
\hline 3. & $\begin{array}{l}\text { Yes } \\
\text { No } \\
\text { Staff RN }\end{array}$ & $\begin{array}{l}\text { Yes } \\
\text { No } \\
\text { Staff RN }\end{array}$ & $\begin{array}{l}\text { Yes } \\
\text { No } \\
\text { Staff RN }\end{array}$ & $\begin{array}{l}\text { Yes } \\
\text { No } \\
\text { Staff RN }\end{array}$ & $\begin{array}{l}\text { Yes } \\
\text { No } \\
\text { Staff RN }\end{array}$ & $\begin{array}{l}\text { Yes } \\
\text { No } \\
\text { Staff RN }\end{array}$ \\
\hline
\end{tabular}




\section{Appendix $\mathbf{J}$}

Data Analysis Table

\begin{tabular}{|c|c|c|c|}
\hline Variables & Type of Data & Statistical Test & Level of Significance \\
\hline 1. Age & Continuous & Frequency, Percentage, Mean, Median, SD & \\
\hline 2. Gender & Nominal & $\begin{array}{l}\text { Frequency and Percentage, Mean, Median, and } \\
\text { SD }\end{array}$ & \\
\hline $\begin{array}{ll}\text { 3. Stages of Pressure } \\
\text { Injuries }\end{array}$ & Nominal & Frequency, and Percentage & \\
\hline 4. Braden Risk Scores & Nominal & $\begin{array}{l}\text { Frequency and Percentage, Mean, Median, and } \\
\text { SD }\end{array}$ & \\
\hline 5. Length of stay & Continuous & Frequency, Percentage, Mean, Median, \& SD & \\
\hline 6. $\quad$ Incidence & Continuous & Frequency, Percentage, and $\mathrm{Z}$ test & $p=.05$ \\
\hline 7. Staff Compliance & Nominal & Frequency \& Percentage & \\
\hline
\end{tabular}




\section{Appendix K}

Evidence Practice Review Council Letter

University of St. Augustine for Health Sciences

Doctor of Nursing Practice Program

Evidence-Based Practice Review Council

1 University Blvd.

St. Augustine, FL 32086

February 13, 2020

Dear Cheryl Cruz

Your proposal titled Reducing the Incidence of Pressure Injuries in Adult ICU patients with a Pressure Injury Preventive Bundle at McAllen Medical Center: A Quality Improvement Project has been reviewed by the University of St. Augustine for Health Sciences Doctor of Nursing Practice Evidence-Based Practice Review Council (EPRC) and determined to:

meet the requirements for research as defined in the Federal Register. You must make adjustments to the proposal to reflect the DNP program requirements $\overline{\text { and }}$ resubmit for additional review. Work closely with your faculty member during this process.

_ X _ not meet the requirements for research as defined in the Federal Register. Your proposal reflects an evidence-based practice change project. The proposal must be implemented as submitted (changes are not permitted). You may proceed to obtain approvals from the facility where the project will be implemented. Implementation may not begin until you are notified in writing by faculty that you may implement the project.

Questions regarding the USAHS approval process should be addressed to Dr. Douglas Turner at DTurner@usa.edu. Questions regarding the facility approval process should be addressed to course faculty.

Sincerely,

Douglas M Turner, PhD, DNP, RN, CNE, NE-BC, NEA-BC 


\section{Appendix L}

\section{Facility Approval Letter}

February 12, 2020

Re: Approval for Implementation of a Quality Improvement Project in Reducing the Incidence of Pressure Injuries in Adult ICU Patients with a Pressure Injury Preventive Bundle Implementation

Dear Dr. Camille Payne,

South Texas Health System McAllen and its Nursing Division recognize the need to implement a quality improvement project utilizing a pressure injury preventive bundle implementation aimed to reduce the incidence of pressure injuries in adult ICU patients at McAllen Medical Center.

The organization does not have an IRB. However, upon the review conducted by the organization's Performance Improvement Committee of the proposed quality improvement project, we are pleased to inform you of our full support and approval for the project's full implementation.

Please do not hesitate to reach out with any question.

Sincerely,

\section{Todd Mann}

Chief Executive Officer

South Texas Health System McAllen

301 West Expressway 83

McAllen, Texas 78503

(956) 632-4008

Todd.mann@uhsrgv.com 
